\title{
IDENTIFYING THE CHARACTERISTICS ASSOCIATED WITH INTIMATE PARTNER STALKING: A MIXED METHODS STRUCTURED REVIEW AND NARRATIVE SYNTHESIS
}

\section{Acknowledgements}

This work was supported by Nottingham Trent University.

\section{Authors/Author biographies}

Dr Caroline Flowers is a Senior Registered Forensic Psychologist employed by Her Majesty's Prison and Probation Service in the United Kingdom. In 2019 she completed a doctorate in forensic psychology at Nottingham Trent University in the area of intimate partner stalking. Her current research interests include intimate partner violence, stalking behaviour, and approaches to intervention for intimate partner stalking perpetrators.

Professor Belinda Winder is a Professor in Forensic Psychology in the United Kingdom. She is Research Director of the Centre for Crime, Offending, Prevention \& Engagement (COPE) in the School of Social Sciences at Nottingham Trent University, and part of the Sexual Offences, Crime and Misconduct Research Unit (SOCAMRU) in the Department of Psychology at Nottingham Trent University. The main focus of her work is applied research in the area of sexual offending and sexual crime, but she also has an interest working with people with lived experience, desistance research and research that contributes to facilitating those with convictions to lead a purposeful life post-conviction.

Dr Karen Slade is Associate Professor of applied forensic psychology at Nottingham Trent University and a Registered forensic psychologist in the United Kingdom. Her research and practice focuses on the areas of self-harm, suicide and violence in forensic populations, the impact on prison staff of working in difficult environments, mental health services for offenders and organisational approaches to suicide and violence prevention.

\section{Funding}

The authors received no financial support for the research, authorship, and/or publication of this article.

\section{Declaration of Conflicting Interests}

The author(s) declare no potential conflicts of interest with respect to the research, authorship, and/or publication of this article.

\section{Ethical approval}

This article does not contain any studies with human participants or animals performed by any of the authors.

\section{Corresponding author}

Dr Caroline Flowers

Email: caroline.flowers02@ntu.ac.uk/ Alternative email: carolineoyibo@yahoo.co.uk 


\begin{abstract}
The empirical research on the clinical management of intimate partner stalking perpetrators remains in the early stages of informing forensic practice. This study presents the first known structured review which seeks to inform intervention pathways for this group through illuminating the characteristics associated with intimate partner stalking. A systematic search was conducted across five academic databases, reference lists of papers were reviewed, and 'experts' contacted to identify relevant papers. The search strategy identified 2,674 papers. Twenty-two studies were selected in line with predetermined inclusion/exclusion criteria and assessed for methodological quality. All studies employed an observational research design; eighteen quantitative, two qualitative, and two mixed methods design studies were included. Data was extracted and subjected to narrative synthesis. Overall, intimate partner stalking perpetrators presented with some similar characteristics to intimate partner violence perpetrators, whilst some characteristics were deemed more prevalent to intimate partner stalking perpetrators. The findings illustrate there are likely to be subtypes of intimate partner stalking perpetrators, requiring a bespoke approach to intervention. Limitations are presented and recommendations made for future research. The wider implications for forensic practice in informing the clinical management of this group and approaches to intervention are discussed.
\end{abstract}

Keywords: Intimate partner stalking; characteristics; intervention; structured review; mixed methods; narrative synthesis. 


\section{Introduction}

Stalking perpetrators ${ }^{1}$ present with diverse characteristics, underpinning motivations, and psychopathology (Nijdam-Jones, Rosenfeld, Gerbrandij, Quick, \& Galietta, 2018). This presenting complexity brings challenges in the clinical management of perpetrators. Intimate partner stalking (IPS) perpetrators are considered the largest subtype (Logan, Shannon, \& Cole, 2007). Compared to other subtypes they have higher recidivism rates (Eke, Hilton, Meloy, Mohandie, \& Williams, 2011; Rosenfeld, 2003), and are deemed the most persistent and potentially dangerous (Mullen, Purcell, \& Stuart, 1999). Given the risks posed by IPS perpetrators, there is merit in obtaining clarity on the underlying characteristics and how best to intervene. Whilst the literature indicates a connection between intimate partner violence (IPV) and stalking behaviour, this remains unclear (Douglas \& Dutton, 2001; Logan, 2010; Gerbrandij, Rosenfeld, Nijdam-Jones, \& Galietta, 2018). Nonetheless, the criminal justice response is to consider IPS under the remit of IPV (Melton, 2012). This approach is adopted in the United Kingdom, with IPS perpetrators considered for intervention designed for IPV perpetrators (L, Jonah, personal communication, September 2015). This practice assumes IPS perpetrators share the same criminogenic needs as IPV perpetrators. Insight into the characteristics of IPS perpetrators would inform how these can be targeted via intervention (Andrews \& Bonta, 2010). Consequently, a review focusing on IPS has value for academia and international policymakers informing on intervention and forensic practice.

\section{The current review}

\footnotetext{
${ }^{1}$ The issue of definition remains a crucial unresolved issue (Owens, 2016), with varying legal, academic, and clinical definitions in the literature (Fox, Nobles, \& Fisher, 2011). A common definition within the stalking risk assessment literature is: "Unwanted and repeated communication, contact, or other conduct that deliberately or recklessly causes people to experience reasonable fear or concern for their safety or the safety of others known to them" (Kropp, Hart, \& Lyon, 2008, p.1).
} 
The Cochrane Database, PROSPERO and Campbell Collaboration were searched for registered systematic reviews. A scoping exercise utilising search terms of 'intimate partner' OR 'partner*' AND 'stalking' OR 'harass' AND 'risk factor', AND 'protective factor' did not identify any reviews focusing on IPS. Two relevant papers were identified; Douglas and Dutton (2001) and Logan (2010). Nonetheless, both presented a narrative literature review not reporting systematic methods. The conclusions drawn identified a gap in the existing literature which the current review seeks to address. Thus, this review aims to understand whether the characteristics of IPS perpetrators are similar or different to IPV perpetrators by answering the following review question: What are the characteristics of men who have engaged in IPS?

\section{Method}

\section{Protocol registration ${ }^{2}$}

The review protocol was registered with the PROSPERO International Prospective Register of Systematic Reviews on the $17^{\text {th }}$ August 2018 (registration number: CRD42018088871).

\section{Review method design}

This review employed a systematic review process (Moher et al., 2015; Petticrew \& Roberts, 2006). The chosen method to present, summarise and synthesise studies was a modified

\footnotetext{
${ }^{2}$ The review protocol can be accessed via the PROSPERO website at http://www.crd.york.ac.uk/prospero/.
} 
narrative synthesis approach (Popay et al., 2006). Narrative synthesis is "an approach to the systematic review and synthesis of findings from multiple sources and relies primarily on the use of words and text to summarize and explain the findings of the synthesis" (Popay et al., 2006, p. 5). This approach captures diversity across studies; enhancing findings and informing policy and practice (Harden \& Thomas, 2010; Joanna Briggs Institute 2014).

\section{Search strategy}

A comprehensive search strategy employing the following search terms was conducted:

Intimate partner: (Partner OR Spous* OR intimate* OR domestic* OR marital* OR romantic* OR civil* OR husband OR boyfriend OR date* OR dating* OR current partner OR prior* OR former* OR ex-intimate* OR couple OR romantic relationship* OR failed romantic relationship*)

AND

Risk factors: (Risk* OR criminogenic need* OR predict* OR static* OR dynamic* OR characteristics OR pathway OR correlate OR factor* OR offender characteristics OR indicator* OR recidiv* OR variable* OR correlate* OR experiences ${ }^{3}$ ).

OR

\footnotetext{
${ }^{3}$ Note: Experiences was incorporated to capture behaviours and experiences described within qualitative literature.
} 
Protective factors: (Protect* OR desistance OR strength OR buffer OR risk moderator).

AND

Stalking behaviour: (Stalk* OR harass* OR pursuit* OR fixat* OR obsess* OR psychosexual obsession OR approach behavior? OR cyberstalk* OR cyber-stalk OR technology facilitated stalk* OR cyber harass* OR omnipresence OR surveillance OR unwanted attention OR predatory pursuit* OR erotomania OR intrusive behavio?r OR intrusive harassment OR simple obsessional stalk* OR rejected stalk* OR relational stalk* OR prior sexual intimate stalk* OR ex-partner harass*).

A structured review protocol was designed in line with a modification of the PICO tool (Petticrew \& Roberts, 2006), incorporating study design to capture quantitative and qualitative studies (See Table 1). [Table 1 insert here]. Five electronic databases were searched between $14^{\text {th }}$ and 15 th February 2018. Database searches generated a total of 2,658 hits, with 162 duplicates removed. Titles and abstracts for 2,496 articles were reviewed, resulting in the exclusion of 2,449 studies. The remaining 47 papers were subjected to a full paper screening, against the inclusion/exclusion criteria, resulting in the exclusion of a further 36 studies. Eleven studies were identified for inclusion from the database search. To widen the search and limit potential publication bias, hand-searching of reference lists, email correspondence with experts, and a search of grey literature was conducted. Three email responses were obtained, identifying no new papers. These additional searches generated a further 16 studies. Five papers were excluded. Searching was updated on the $31^{\text {st }}$ May 2018 , identifying no additional papers. A total of 22 studies (11 from database searching, and 11 
from hand-searching) were included in the review and subjected to quality assessment. Figure 1 shows the PRISMA flowchart of the study selection process. [Figure 1 insert here]

\section{Quality assessment}

To prevent bias, studies were not selected based on quality during the search process (Petticrew \& Roberts, 2006). Twenty-two studies remaining were assessed for methodological quality by the review author using a checklist designed for quantitative, qualitative, or mixed methods studies. Quantitative papers were assessed using a modification of the Downs and Black (1998) checklist, qualitative papers by the Critical Appraisal Skills Programme (CASP, 2006) checklist, and mixed methods studies adapted from the above two quality assessments. Each item on the quality assessment form was scored on a three-point Likert scale $($ criterion fully met $=$ two, partially met $=$ one, not met/unclear, zero), calculating an overall quality score for each study. Items were omitted not applicable to the study design. The overall quality score for each paper was calculated by summing all the scores together. Maximum score attainable for quantitative papers was 46, qualitative papers 36 , and mixed methods 44 . The overall score for each paper was calculated, with higher scores reflecting a higher quality paper. Scores were converted into percentages, enabling a clear comparison of quality between studies. Each study was categorised a rating of 'high quality' (100-70\%), 'moderate quality' (69-30\%) and 'low quality' (0-29\%). A sample of quality assessments were subjected to inter-rater reliability by the second author.

\section{Data extraction and thematic synthesis}


A data extraction table was created (see Table 2) outlining relevant data pertaining to each study (Petticrew \& Roberts, 2006), allowing conclusions to be drawn from the review. [Insert table 2 here]. A thematic synthesis of included studies was conducted using the principles of thematic analysis (Harden \& Thomas, 2010; Popay et al., 2006) to analyse and report on the characteristics associated with IPS perpetrators. Each study was summarised. Data was organised into preliminary descriptive themes. The final stage involved defining and renaming preliminary themes through a process of deeper interpretation to generate 'analytical' themes and final themes, enabling the identification of recurring themes in relation to the review question.

\section{Findings}

Twenty-two studies were included in the review. The research designs of included studies are firstly described, followed by a qualitative synthesis of the findings.

\section{Study characteristics}

Nine studies reported on perpetrator samples $[1,2,3,4,5,10,12,15,16]$, thirteen on victim samples $[6,7,8,9,11,13,14,17,18,19,20,21,22]$. Two studies $[7,8]$ used the same data, reporting separate results. Twenty-one studies were published articles. One study was a $\mathrm{PhD}$ thesis [3]. Studies were published between 1997 and 2018. Sixteen studies originated from the United States, four from Australia, one from Portugal, and one from the UK.

\section{Study design}


All studies employed an observational research design ${ }^{4}$; eighteen quantitative $[1,2,3,4,5$, $8,10,11,12,13,14,16,17,18,20,21,22]$; two qualitative, [6,19]; and two mixed method studies [7, 15]. Five studies incorporated a comparison group [1, 2, 12, 16, 20], comprising: non-intimate stalking compared to IPS [1, 12]; IPV perpetrators who engaged in stalking behaviours and those that did not $[2,16]$, and stalking victims with and without a history of IPV [20]. One study used a control group comprising women who had not reported IPV within the year prior to attempted or actual femicide [21]. Data was obtained from official archive case file records, psychometrics/surveys, interview, or combination of these methods.

\section{Setting and samples}

Ten studies were selected from community samples $[6,7,8,9,13,14,18,19,20,21]$; three from a specialist stalking intervention facility $[4,10,12]$; four from a community or custodial forensic intervention facility $[2,3,15,16]$; and three from police settings $[1,11$, 22]. Convenience sampling was the typical sampling strategy employed. Sample sizes varied depending on the research design. Perpetrator samples ranged from 36 to 1,785 , with a combined perpetrator sample of 3,015. Victim samples ranged from 21 to 464, with overall sample size of 1,427 .

\section{Measures}

All studies provided a definition of stalking, varying dependent on the publication year, country psychometric measure used. A range of psychometrics were employed as outcome

\footnotetext{
${ }^{4}$ See Table 2 - The data extraction table outlines study design and type of analysis.
} 
measure for stalking perpetration. Ten studies employed self-report surveys/psychometrics $[1,2,3,9,13,14,15,16,17,20]$. Qualitative studies employed interviews and questionnaires but did not report on validation or reliability $[6,7,19]$.

\section{Quality appraisal}

Studies achieved quality scores ranging between $39 \%$ and $85 \%$. Eight studies were considered 'high quality', 14 moderate, with no papers deemed low quality. Higher scoring studies were recent quantitative papers from Australia from the specialist stalking clinic [4, $10,12]$.

\section{Narrative synthesis}

Synthesis of the 22 studies provides an overview of the research, illuminating insight into the profile of IPS perpetrators. The following overarching themes were present and connected the studies: (1) Perpetrator demographics; (2) Relationship history and dynamics; (3) Perpetrator background factors; and (4) Nature of stalking. (See table 3). [Table 3 insert here]. Findings are discussed in relation to the wider literature, and comparisons made to IPV literature.

Theme 1: Perpetrator demographics 
This theme captures the demographic characteristics associated with the profile of IPS. Most studies centred on age, with limited studies reporting educational attainment, employment status and ethnicity. All studies included demographic variables as descriptors. No study explored demographic factors as predictors to investigate how the relationship between age, ethnicity, educational attainment, and employment were related to stalking recidivism. No studies utilised comparison groups. Twelve studies reported age at the time of stalking perpetration $[1,2,3,4,5,8,10,11,12,15,16,22]$. Across studies, age ranged between 17 and 80 years, with the mean age of 34.3 years. This finding is consistent with the general stalking literature, with age spanning from teens to 70 years plus (Jordan, Logan, Walker, \& Nigoff, 2003). In contrast, age is reported as a protective factor for IPV, with older age decreasing IPV perpetration (Capaldi, Knoble, Shortt, \& Kimm, 2012). Seven studies reported education and employment status $[2,3,4,8,10,11,15]$. The findings indicate unemployment is a demographic characteristic for IPS; paralleling the IPV literature (Capaldi et al., 2012). Seven studies reported ethnicity $[2,3,5,8,15,16,20]$. Caucasians were overrepresented in samples. It is unclear whether proportionately perpetrators matched the demographics of the area from where the sample was drawn.

Summary: Where there is commonality between IPS and IPV perpetration relates to problems with employment. No conclusive findings can be drawn on the demographic profiles of IPS perpetrators.

\section{Theme 2: Relationship history and dynamics}


This theme reflects the relationship history of IPS perpetrators. Two subthemes underpin this theme; (1) Victim-perpetrator relationship; and (2) Prior history of IPV.

\section{2a) Victim-perpetrator relationship.}

This subordinate theme represents the relationship status at the onset of stalking behaviour. Prior relationship history is reported in 12 studies $[2,3,4,8,9,11,14,15,16,17$, $20,22]$. Eleven studies indicate the stalking campaign began by a current partner while the relationship was intact $[2,3,4,8,9,11,14,15,16,20,22]$, with between $21 \%$ [11] and $80.9 \%$ of victims reporting this [9]. Two studies utilised comparator groups $[9,11]$.

Compared to IPV perpetrators who do not stalk, the victim-perpetrator relationship was found to be a considerable factor.

Summary: Whilst there is an indication IPS perpetrators are less likely to be in a relationship at the onset of the stalking campaign, stalking behaviour is also reported to begin when the relationship is intact; thus, reporting mixed findings. This theme is supported by five high quality studies and seven moderate quality studies, indicating strong evidence for this theme.

\section{2b) Prior history of intimate partner violence.}

This subordinate theme describes whether a previous history of IPV during the relationship preceded stalking behaviour. Fourteen studies report on the presence of prior IPV; eleven from victims $[6,7,8,9,11,13,14,17,18,20,21]$ and three from perpetrator samples $[2,3,4]$. Victims reported the presence of prior IPV ranged from $39 \%$ to $85 \%[6,7$, 
$8,11,13,18]$; Physical abuse between $39 \%$ and $62 \%$, psychological abuse $53 \%$ to $82 \%[6,7$, $14]$ and sexual abuse $8.6 \%$ to $82 \%[6,8]$. In contrast, perpetrator samples reported ranges between $24 \%$ and $62 \%[2,3,4]$. Controlling behaviour and psychological violence are strongly associated with IPV (Brownridge et al., 2013). One study found no relationship between stalking behaviour and previous IPV [1]. One study [20] reported $69 \%$ of victims acknowledged perpetrating physical and/or psychological abuse during the relationship, indicating a level of bidirectionality of IPV. Some studies suggest psychological rather than physical violence is more prevalent $[4,17,21]$. Two in three perpetrators had a protective order before or after their stalking charge, supporting a link between IPV and stalking; $32 \%$ had at least one previous domestic violence order and 53\% a prior conviction [5]. Problems with intimate relationships is cited as risk factor for IPV (Kropp \& Hart, 2015), with separation/relationship breakdown considered a critical factor (Dutton \& Kropp, 2000; Williams \& Houghton, 2004).

Summary: The findings suggest IPS co-occurs with physical, sexual, and psychological violence, with perpetrators breaching restrictions/supervision measures. The presence of previous psychological violence maybe a more robust factor than physical violence. This theme is supported by six high quality studies and eight moderate quality studies, indicating strong evidence for this theme.

Theme 3: Perpetrator background factors 
This theme integrates findings reflecting a range of perpetrator background factors pertinent to the profile of IPS perpetrators. There are three interlinked subthemes; (1) Psychological and clinical characteristics, (2) History of substance abuse; and (3) Past criminal history.

\section{3a) Psychological and clinical characteristics.}

Personality pathology and clinical syndromes including Axis 1 and Axis II disorders was reported in eight studies $[1,2,3,4,9,11,12,15]$. Axis 1 diagnosis (excluding psychotic disorder) was present in $40.5 \%$ of cases [12]. One in fifty were identified as having a psychotic illness [4]. Antisocial and borderline personality disorder were the most commonly reported, paralleling the IPV literature (Dutton \& Kropp, 2000). This finding supports similarities in the profile of IPS and IPV perpetrators, and research from Douglas and Dutton (2001) and Holtzworth-Munroe \& Stuart (1994) borderline-dysphoric typology. Nonetheless, a broader spectrum of personality disorders has not been investigated in the literature (Nijdam-Jones et al., 2018).

Summary: The presence of personality disorder is common amongst both IPS and IPV perpetrators; most typically antisocial and borderline. This subordinate theme is supported by six high quality studies and two moderate quality studies, indicating moderate evidence for this theme.

\section{3b) History of substance misuse.}


This theme captures the role of alcohol and drug abuse in the pathway to IPS. Substance misuse problems was a central factor underpinning the histories of IPS perpetrators, with this theme occurring across eleven papers. Four papers reported on the perspective of the victim $[7,8,9,13]$, and seven on perpetrator samples $[1,2,3,11,1215,16]$. Victims reported the prevalence of substance misuse ranged between $53.5 \%$ (12) and 72\% [7], with perpetrators reporting between $36 \%$ (15) and 37\% [16]. The prevalence of drug use reported by perpetrators was $3.8 \%$ [15], with victims reporting higher figures, ranging from $51 \%$ (8) to $55 \%$ [7]. Two studies reported on a comparator group. Compared to IPV perpetrators who do not stalk, those who had engaged in IPS were more likely to have alcohol or drug problems $[16,19]$. Whilst this is a notable finding, gaps remain in understanding the role this plays. Questions remain whether this is due to underlying dependency or a coping strategy in response to relationship breakdown. Alcohol abuse is recognised as a risk factor for IPV (Capaldi et al., 2012; Corvo \& Johnson, 2013), whereas drug use has not been widely explored as a risk factor for IPV (Capaldi et al., 2012).

Summary: The findings suggest that an area of similarity between IPS and IPV perpetrators is substance misuse, particularly alcohol. Substance misuse was identified by both victim and perpetrator samples, strengthening the robustness of this as a characteristic of IPS perpetration. This theme is supported by six high quality studies and four moderate quality studies indicating robust evidence for this theme.

\section{3c) Past criminal history.}


This theme encapsulates the non-partner past criminal histories of IPS perpetrators, including offending behaviour and history of supervision failures. Five studies reported this factor $[1,3,8,13,16]$. Prior arrest for violence against a person ranged from $78.6 \%$ and $79.3 \%[3,13]$; victims were distributed evenly across family members, friends/acquaintances, and strangers [3]. Weapon use was reported by $8 \%$ of perpetrators [3]. Violation orders was found in $36 \%$ of cases [13]. Two studies reported on comparator groups [2, 16]. A previous criminal history was greater in IPS perpetrators compared to other subtypes of stalking perpetrators [2]. The highest correlation differentiating those who reported stalking and those who did not was whether that person had a history of stalking another victim [16]. These findings are consistent with the IPV literature. That is, an antisocial lifestyle is deemed a risk factor for IPV (Hilton, et al., 2004), along with a prior history of violence perpetrated against non-intimate family members (Hendy, Burns, Can \& Scherer, 2012), and previous supervision violations (Kropp \& Hart, 2015; Russell, 2012). In contrast, the general stalking literature has found mixed empirical evidence for the role of a prior criminal history. Some studies reported such a history increased risk of stalking violence (Mullen, et al., 1999, Sheridan \& Davies, 2001), whereas a meta-analysis found this was not a consistent finding (Rosenfeld, 2004).

Summary: Limited studies have explored a non-partner offending history. Findings indicate that IPS perpetrators are likely to have a criminal history, including the use of nonpartner violence and supervision violations. This theme is supported by three high quality studies and two moderate quality studies, indicating moderate support for this theme.

\section{Theme 4: Nature of stalking}


This theme captures the behavioural profile of IPS perpetrators. There are three subthemes: (1) Onset of stalking: Motivation and triggers; (2) Pursuit tactics; (3) Threats and escalation.

4a) Onset of stalking: Motivation and triggers.

Nine studies report on motivational factors; five from victims $[6,7,9,19,21]$ and three from perpetrators $[3,15,16]$. IPS appears to be driven by a combination of non-malicious and malicious motives; including a desire to reconcile a relationship, to show love, need to communicate, desire for revenge/punish/humiliate, access to children. The most common being to reconcile a relationship. Perpetrators presented with less malicious motives. Motives for IPS appear to be similar to those identified in the IPV literature (Langhinrichsen-Rohling, McCullars, \& Misra, 2012).

Summary: Victim and perpetrator studies identified similar motives including both nonmalicious intent for stalking behaviour with similarity between IPS and IPV perpetrators. This theme is supported by two high quality studies $[3,9]$ and six moderate quality studies $[6$, $7,15,16,19,21]$, indicating moderate support for this theme.

4b) Pursuit tactics. 
Fourteen studies report on methods of pursuit $[1,2,3,6,8,9,11,12,13,14,15,18,19$, 20]. IPS employ a range of stalking tactics categorised into; direct methods of unwanted communication, approach behaviours, technology-facilitated stalking and proxy stalking. The most common being unwanted communication and approach behaviours. The most frequent self-reported behaviour was making unwanted phone calls, ranging between $4.2 \%$ to $69 \%$ from perpetrators. Sending gifts/flowers/items ranged between $24.2 \%$ to $40 \%[2,3,15]$. Written communication ranged between $10.9 \%$ and $31 \%[2,3,10,15]$. The most common approach behaviour was turning up unexpectedly at the victims' home, workplace, or other public place; ranging between $22 \%$ to $61.9 \%$ [2, 3, 13, 14]. Physical following ranged from $6 \%$ to $22.5 \%[3,12]$. Spying/watching ranged from $6.7 \%$ to $76 \%[9,12,13,14]$, trespass on victims' property ranged from $2.9 \%$ to $79 \%[11,12,18]$. Spying, surveillance and physical following was highlighted as the most dangerous behaviours $[17,21]$. Two studies reported on technology-facilitated stalking $[6,14]$. Victims reported text messaging and telephoning was the most common method. GPS mobile technology and social media were also cited as a platform to facilitate stalking behaviour, to obtain knowledge but also to publicly humiliate and punish. Proxy stalking was identified in three studies $[3,6,9]$; ranging between $18 \%$ and 52.4\%. Studies with comparator groups, found that victims who reported previous IPV experienced a high number of different acts of stalking than those who did not [20]. Limited research explored persistence $[8,12,16,20]$. Wide variations were identified; thus, no conclusive findings can be drawn.

Summary: IPS perpetrators employ a variety of methods or patterns of behaviours in pursuit of the victim. This theme is supported by seven high quality studies $[1,3,12,11,9,30,20]$ and seven moderate quality study $[2,6,15,18,8,14,19]$, indicating strong evidence for this theme. 


\section{4c) Threats and escalation.}

This theme captures threating communication and acts of physical harm towards either the primary victim or secondary target. Use of threats and escalation to violence was a central factor in IPS perpetrators, and predictor of violence. This theme occurred in eight papers [1, $3,7,8,9,1218,20]$. The use of violence ranged between $3.5 \%$ and $89 \%[3,13]$. The discrepancy reflects the self-report by perpetrators that violence was uncommon, compared to victim accounts, which stated physical violence ranged between $45 \%$ and $89 \%[13,18]$. Use of weapons ranged between $5 \%$ [11] and $39.6 \%$ when stalking had escalated to attempted/actual homicide [21]. IPS perpetrators are more likely to use threats and violence compared to other subtypes of stalking perpetrators and more likely to act with violence if threats have been made. Two studies explored stalking as a risk factor for homicide [17, 21$]$. Findings suggest stalking in intimate partner homicide victims ranged from $23.4 \%$ to $76 \%$. In cases where stalking escalated to attempted/actual homicide, $54.5 \%$ had previously threatened to kill the victim [21]. The findings from this review provide robust evidence to indicate a link between intimate partner homicide and stalking. The findings parallel the IPV literature indicating strong evidence for this theme and similarities in the profiles of IPS and IPV perpetrators. Threats to kill is a risk factor for IPV (Dutton \& Kropp, 2000), with femicide occurring in the context of separation/relationship breakdown (Morgan \& Gilchrist, 2010).

Summary: The use of threats is widely cited as a characteristic of IPS perpetrators, with evidence indicating the presence of prior threats is a predictor of future violence. This finding supports similarity in the profiles of IPS and IPV perpetrators. Critical behavioural 
characteristics are threats, following through on threats, and escalation to violence, with robust evidence to indicate a link between intimate partner homicide and stalking. This theme is supported by five high quality studies $[1,3,9,12,20]$ and three moderate quality studies $[7,8,18]$ indicating robust evidence for this theme.

\section{Discussion}

This review aimed to advance understanding on the characteristics of IPS perpetrators, and to this end the aims have been met. Limitations are now discussed, along with applications to forensic practice and research.

\section{Limitations}

\section{Bias}

A systematic approach limits bias, providing transparency in reporting the findings (Sayers, 2007). Searching by the review author was robust. Incorporating perpetrator and victim samples across multiple settings provides a more representative overview. Nonetheless, the review is not without limitations, influencing the strength of the conclusions drawn. Sources of bias include, restricting searching to five electronic databases, excluding papers not written in English language, restricting searching to one reviewer, and subjecting a sample of studies to inter-rater reliability. 
Studies varied in overall quality, attaining quality scores between $39 \%$ and $85 \%$. Quality assessment identified methodological limitations among the studies which require consideration. No papers employed a randomised control design or other experimental designs. No longitudinal studies were found which would seek to ascertain direction of causality for risk factors. Methodological design was restricted to observational studies with potential for bias and confounding variables. Studies employed several data collection techniques; case files, psychometric/questionnaires, and interview. As such, the limitations of these methods apply to this review. All studies adopted a retrospective design from a convenience sample. There is potential for underreporting or exaggerated accounts from victims. For perpetrators there is the potential for bias due to social desirability and overreliance on recognising and describing behaviour. For studies using case file data, there is reliance on the accuracy and quality of retrospective clinical/police reporting. Furthermore, samples are not reflective of all levels of stalking behaviour, with clinical samples predominantly including low-level and moderate-level perpetrators. There is a lack of samples from prison settings reflecting those convicted of serious stalking violence. Significantly, there was a lack of studies utilising a control/comparison group. Whilst five studies used a comparison group, only two employed comparison groups differentiating IPV and IPS perpetrators $[2,16]$. The lack of comparison/control groups makes it unclear whether the themes identified were unique to IPS perpetrators. There was a lack of robust qualitative studies within the review, with such studies coming from victim samples. All were deemed moderate quality, lacking transparency and clarity on elements of the research design.

\section{Definition and outcome measures.}


Definitions of stalking across studies varied, due to the diversity of publications across a twenty-year timespan and across countries with different and changing legislation. Due to cultural variables the results may not be representative of IPS perpetrators internationally. A range of outcome measures were used for stalking and IPV, some of which were not standardised or validated. There is also variability in the theoretical models underpinning the conceptual frameworks of included studies.

\section{Conclusions and recommendations}

The findings further illuminate the theoretical debate on the connection between IPV and IPS. The review indicates there are some characteristics (i.e., personality disorder, substance misuse, history of IPV, prior criminal history, and unemployment) deemed similar to IPV perpetrators, and some characteristics (i.e. age, type of personality disorder, psychological violence, and behavioural patterns) more prevalent to IPS perpetrators. A key finding is that the literature suggests IPS perpetrators are not a homogenous group, and there are likely to be subtypes of IPS perpetrators.

\section{Implications for future research}

The review has identified gaps in the literature where further research is warranted to address the recommendations of this review and inform forensic practice. Half the studies emerge from the last decade, demonstrating the evolving nature of the stalking literature. There is a lack of research from the UK. Greater variety of study designs are warranted to further understand IPS. There are no known studies exploring obsession, a striking finding given obsession is regarded as a factor in stalking perpetration. There are no qualitative 
studies exploring characteristics from the perspective of the perpetrator. A phenomenological approach has the potential to illuminate the pathway to IPS, providing understanding into perpetrators experiences and relationship patterns that cannot be accessed through other methods. There is a gap in understanding the role of trauma and stress in IPS perpetration, clarity on type of personality disorder, and the role of technology-facilitated stalking. Additionally, there is a lack of research from the field of neuropsychology and new theoretical frameworks (i.e. implicit theories). This review originally attempted to include protective factors. However, no studies were identified, highlighting a lack of understanding as to what prevents IPS. Such studies have the capacity to enhance clinical and risk management and is an area warranting urgent exploration. There is also a dearth of research exploring stalking persistence with emphasis specifically on IPS perpetrators.

\section{Implications for forensic practice}

The findings have strong practical application for international policymakers and practitioners in informing the clinical management of IPS perpetrators, demonstrating promise for informing future directions for intervention pathways. The finding that IPS perpetrators are not a homogenous group has wider implications for policymakers and those designing interventions. Interventions specific to this group are not compatible with a 'onesize-fits-all' approach. Whilst IPS perpetrators appear to share some commonalities with IPV perpetrators, indicating IPV intervention may address some characteristics, they likely possess some distinct characteristics not currently targeted on IPV interventions. As such, it is not possible to infer that IPV intervention will address all the needs of IPS perpetrators. Given the definition of stalking is underpinned by obsessive thinking, it is hypothesised that obsessive cognitive characteristics are a potential critical factor in stalking perpetration that 
current IPV interventions are unlikely to address. Thus, IPS perpetrators may have a greater level of criminogenic need compared to IPV perpetrators, specifically relating to the possible presence of other type of personality disorder and characteristics which drive psychological violence. This review supports the views expressed in previous literature (McEwan et al. 2017; Purcell \& McEwan, 2018). To this end and in light of the review findings, adopting a bespoke approach to intervention is warranted. Significantly, there is likely to be merit in sequencing interventions, particular given the findings this group presents with characteristics linked to substance abuse and psychopathology, which may be deemed intervention interfering factors. Given the above, there is value in considering how the review findings can be disseminated and implemented by practitioners and policymakers to inform the clinical management of IPS.

\section{References}

\section{*References included in the structured review}

Andrews, D. A., \& Bonta, J. (2010). Rehabilitating criminal justice policy and practice. Psychology, Public Policy, and Law, 16(1), 39-55. doi:10.1037/a0018362

*Brady, P. Q., \& Hayes, B. E. (2018). The intersection of stalking and the severity of intimate partner abuse. Violence and victims, 33(2), 218-238.

*Brewster, M. P. (2000). Stalking by former intimates: Verbal threats and other predictors of physical violence. Violence and Victims, 15(1), 41-54.

*Brewster, M. P. (2003). Power and control dynamics in prestalking and stalking situations. Journal of Family Violence, 18(4), 207-217. doi:10.1023/A:1024064214054

Brownridge, D. A., Taillieu, T. L., Tyler, K. A., Tiwari, A., Chan, K. L., \& Santos, S. C. (2011). Pregnancy and intimate partner violence: risk factors, severity, and health effects. Violence against women, 17(7), 858-881.

*Burgess, A., Baker, T., Greening, D., Hartman, C., Burgess, A., Douglas, J., \& Halloran, R. (1997). Stalking behaviors within domestic violence. Journal of Family Violence, 12(4), 389-403. doi:10.1023/A:1021931509143 
*Burgess, A., Harner, H., Baker, T., Hartman, C., \& Lole, C. (2001). Batterers stalking patterns. Journal of Family Violence, 16(3), 309-321. doi:10.1023/A:1011142400853

Capaldi, D., Knoble, N., Shortt, J., \& Kim, H. (2012). A systematic review of risk factors for intimate partner violence. Partner Abuse, 3(2), 231-280. doi:10.1891/1946-6560.3.2.231

Critical Appraisal Skills Programme (CASP) (2006). 10 questions to help you make sense of qualitative research. England. Public Health Resource Unit.

Corvo, K., \& Johnson, P. (2013). Sharpening Ockham's Razor: The role of psychopathology and neuropsychopathology in the perpetration of domestic violence. Aggression and violent behavior, 18(1), 175-182.

Douglas, K. S., \& Dutton, D. G. (2001). Assessing the link between stalking and domestic violence. Aggression and Violent Behavior, 6(6), 519-546. doi:10.1016/S13591789(00)00018-5

Downs, S. H., \& Black, N. (1998). The feasibility of creating a checklist for the assessment of the methodological quality both of randomised and non-randomised studies of health care interventions. Journal of Epidemiology \& Community Health, 52(6), 377-384.

Dutton, D. G., \& Kropp, P. R. (2000). A review of domestic violence risk instruments. Trauma, Violence, \& Abuse, 1(2), 171-181. doi:10.1177/1524838000001002004

Eke, A. W., Hilton, N. Z., Meloy, J. R., Mohandie, K., \& Williams, J. (2011). Predictors of recidivism by stalkers: A nine-year follow-up of police contacts. Behavioral Sciences \& the Law, 29(2), 271. doi:10.1002/bsl.975

*Ferreira, C., \& Matos, M. (2013). Post-relationship stalking: The experience of victims with and without history of partner abuse. Journal of Family Violence, 28(4), 393-402. doi:10.1007/s10896-013-9501-5

Fox, K. A., Nobles, M. R., \& Fisher, B. S. (2011). Method behind the madness: An examination of stalking measurements. Aggression and Violent Behavior, 16(1), 74-84.

doi:10.1016/j.avb.2010.12.004

Gerbrandij, J., Rosenfeld, B., Nijdam-Jones, A., \& Galietta, M. (2018). Evaluating risk assessment instruments for intimate partner stalking and intimate partner violence. Journal of Threat Assessment and Management, 5(2), 103.

Harden, A., \& Thomas, J. (2010). Mixed methods and systematic reviews: Examples and emerging issues. Sage handbook of mixed methods in social \& behavioral research, 2, 749-774.

Hendy, H. M., Burns, M. K., Can, S. H., \& Scherer, C. R. (2012). Adult violence with the mother and sibling as predictors of partner violence. Journal of interpersonal violence, 27(11), 22762297. 
Hilton, N. Z., Harris, G. T., Rice, M. E., Lang, C., Cormier, C. A., \& Lines, K. J. (2004). A brief actuarial assessment for the prediction of wife assault recidivism: the Ontario domestic assault risk assessment. Psychological assessment, 16(3), 267.

Holtzworth-Munroe, A., \& Stuart, G. L. (1994). Typologies of male batterers: Three subtypes and the differences among them. Psychological Bulletin, 116(3), 476. doi:10.1037/00332909.116.3.476

Joanna Briggs Institute. (2014). Joanna Briggs Institute reviewers' manual: 2014 edition. Australia: The Joanna Briggs Institute.

Jordan, C. E., Logan, T. K., Walker, R., \& Nigoff, A. (2003). Stalking: An examination of the criminal justice response. Journal of Interpersonal Violence, 18(2), 148-165.

Kropp, P. R., \& Hart, S. D. (2015). SARA-V3. User guide for the third edition of the spousal assault risk assessment guide.

Kropp, P. R., Hart, S. D., Lyon, D. R. (2008). Stalking Assessment and Management. Vancouver, BC: Proactive Resolutions, Inc.

Langhinrichsen-Rohling, J., Mccullars, A., \& Misra, T. (2012). Motivations for men and women's intimate partner violence perpetration: A comprehensive review. Partner Abuse, 3(4), 429468. doi:10.1891/1946-6560.3.4.429

Logan, T. (2010). Research on partner stalking: Putting the pieces together. Lexington, KY: University of Kentucky, Department of Behavioral Science \& Center on Drug and Alcohol Research.

*Logan, T. K., Nigoff, A., Walker, R., \& Jordon, C. (2002). Stalker profiles with and without protective orders: Reoffending or criminal justice processing? Violence and Victims, 17(5), 541-53. doi:10.1891/vivi.17.5.541.33713

Logan, T. K., Shannon, L., \& Cole, J. (2007). Stalking victimization in the context of intimate partner violence. Violence and Victims, 22(6), 669. doi:10.1891/088667007782793147

*McEwan, T. E., Daffern, M., Mackenzie, R. D., \& Ogloff, J. R. P. (2017). Risk factors for stalking violence, persistence, and recurrence. The Journal of Forensic Psychiatry \& Psychology, 28(1), 38-56. doi:10.1080/14789949.2016.1247188

*McEwan, T. E., MacKenzie, R. D., Mullen, P. E., \& James, D. V. (2012). Approach and escalation in stalking. Journal of Forensic Psychiatry \& Psychology, 23(3), 392-409. doi:10.1080/14789949.2012.679008

*McEwan, T. E., Shea, D. E., Nazarewicz, J., \& Senkans, S. (2017). Reassessing the link between stalking and intimate partner abuse. Partner Abuse, 8(3), 223-250. doi:10.1891/19466560.8.3.223

*McFarlane, J., Campbell, J. C., \& Watson, K. (2002). Intimate partner stalking and femicide: Urgent implications for women's safety. Behavioral Sciences \& the Law, 20(1-2), 51. doi: $10.1002 / \mathrm{bs} 1.477$ 
*McFarlane, J. M., Campbell, J. C., Wilt, S., Sachs, C. J., Ulrich, Y., \& Xu, X. (1999). Stalking and intimate partner femicide. Homicide Studies, 3(4), 300-316. doi:10.1177/1088767999003004003

*Mechanic, M. B., Weaver, T. L., \& Resick, P. A. (2000). Intimate partner violence and stalking behavior: Exploration of patterns and correlates in a sample of acutely battered women. Violence and Victims, 15(1), 55-72.

*Melton, H. C. (2007a). Predicting the occurrence of stalking in relationships characterized by domestic violence. Journal of Interpersonal Violence, 22(1), 3-25.

*Melton, H. C. (2007b). Stalking in the context of intimate partner abuse: in the victims' words. Feminist Criminology, 2(4), 347-363.

Melton, H. C. (2012). Stalking, intimate partner abuse, and the police. The Open Criminology Journal, 5(1), 1-7. doi:10.2174/1874917801205010001

Moher, D., Shamseer, L., Clarke, M., Ghersi, D., Liberati, A., Petticrew, M., ... \& Stewart, L. A. (2015). Preferred reporting items for systematic review and meta-analysis protocols (PRISMA-P) 2015 statement. Systematic reviews, 4(1), 1.

Morgan, W., \& Gilchrist, E. (2010). Risk assessment with intimate partner sex offenders. Journal of Sexual Aggression, 16(3), 361-372. doi:10.1080/13552600.2010.502976

Mullen, P. E., Purcell, R., \& Stuart, G. W. (1999). Study of stalkers. American journal of psychiatry, 156(8). 244-1249.

* Nicastro, A. M., Cousins, A. V., \& Spitzberg, B. H. (2000). The tactical face of stalking. Journal of Criminal Justice, 28(1), 69-82. doi:10.1016/S0047-2352(99)00038-0

Nijdam-Jones, A., Rosenfeld, B., Gerbrandij, J., Quick, E., \& Galietta, M. (2018). Psychopathology of stalking offenders: Examining the clinical, demographic, and stalking characteristics of a community-based sample. Criminal Justice and Behavior, 45(5), 712-731. doi:10.1177/0093854818760643

*Norris, S. M., Huss, M. T., \& Palarea, R. E. (2011). A pattern of violence: Analyzing the relationship between intimate partner violence and stalking. Violence and Victims, 26(1), 103-115.

Owens, J. G. (2016). Why definitions matter. Journal of Interpersonal Violence, 31(12), 2196-2226.

*Palarea, R. E. (2005). An empirical analysis of stalking as a risk factor in domestic violence Available from PsycINFO. (621046660; 2005-99006-045). Retrieved from http://search.proquest.com/docview/621046660?accountid=14693

*Palarea, R. E., Zona, M. A., Lane, J. C., \& Langhinrichsen-Rohling, J. (1999). The dangerous nature of intimate relationship stalking: Threats, violence, and associated risk factors. Behavioral Sciences and the Law, 17(3), 269-283. 
Pettigrew, M., \& Roberts, H. (2006). Systematic reviews in the social sciences: A practical guide. Oxford: Blackwell Publishing.

Popay, J., Roberts, H., Sowden, A., Petticrew, M., Arai, L., Rodgers, M., ... \& Duffy, S. (2006). Guidance on the conduct of narrative synthesis in systematic reviews. A product from the ESRC methods programme Version, 1.

Purcell, R., \& McEwan, T. (2018). Treatment approaches for stalking. In Violent and Sexual Offenders (pp. 428-444). Routledge.

Rosenfeld, B. (2003). Recidivism in stalking and obsessional harassment. Law and Human Behavior, 27(3), 251-265.

Rosenfeld, B. (2004). Violence risk factors in stalking and obsessional harassment A review and preliminary meta-analysis. Criminal Justice and Behavior, 31(1), 9-36.

Russell, B. (2012). Effectiveness, victim safety, characteristics, and enforcement of protective orders. Partner Abuse, 3(4), 531-552.

Sayers, A. (2007). Tips and tricks in performing a systematic review. The British Journal of General Practice: The Journal of the Royal College of General Practitioners, 57(545), 999. doi:10.3399/096016407782604938

*Sheridan, L., \& Davies, G. M. (2001). Violence and the prior victim-stalker relationship. Criminal Behaviour and Mental Health, 11(2), 102-116.

*Tjaden, P., \& Thoennes, N. (2000). The role of stalking in domestic violence crime reports generated by the colorado springs police department. Violence and Victims, 15(4), 427-441.

Williams, K., \& Houghton, A. (2004). Assessing the risk of domestic violence reoffending: A validation study. Law and Human Behavior, 28(4), 437-455. doi:10.1023/B:LAHU.0000039334.59297.

*Woodlock, D. (2017). The abuse of technology in domestic violence and stalking. Violence Against Women, 23(5), 584-602. doi:10.1177/1077801216646277 
Tables

Table 1 - Inclusion and Exclusion Criteria

\begin{tabular}{|c|c|c|}
\hline Concept & Inclusion Criteria & Exclusion Criteria \\
\hline Population & $\begin{array}{l}\text { Male IPV perpetrators (aged } 16 \\
\text { years and over) at time of stalking } \\
\text { behaviour. } \\
\text { Any nationality, ethnicity and level } \\
\text { of cognitive functioning } \\
\text { No restrictions on type of setting - } \\
\text { samples taken from both forensic, } \\
\text { clinical settings in community and } \\
\text { custody, police. } \\
* \text { Note: Mixed gender samples will } \\
\text { be included when author specifies } \\
\text { number of females in the sample } \\
\text { and when >90\% of sample are } \\
\text { male. } \\
\text { Mixed subtypes of stalking } \\
\text { perpetrators included if authors give } \\
\text { breakdown specific to IPS for } \\
\text { conclusions to be drawn. }\end{array}$ & $\begin{array}{l}\text { Males under the age of } 16 . \\
\text { Predominantly female samples } \\
\text { Predominantly same-sex } \\
\text { relationship samples } \\
\text { Study does not include } \\
\text { perpetrators with stalking } \\
\text { behaviour } \\
\text { *Note: Samples with mixed } \\
\text { subtypes of stalker excluded if } \\
\text { authors do not provide breakdown } \\
\text { specific to IPS. }\end{array}$ \\
\hline Interventions & $\begin{array}{l}\text { Risk factors, clinical, offence or } \\
\text { demographic characteristics } \\
\text { Factors predicting stalking } \\
\text { recidivism } \\
\text { Protective factors }\end{array}$ & $\begin{array}{l}\text { No examination of risk factors / } \\
\text { characteristics, factors predicting } \\
\text { stalking behaviour/recidivism }\end{array}$ \\
\hline Comparators & $\begin{array}{l}\text { Studies eligible for inclusion } \\
\text { whether or not they included a } \\
\text { comparator group. Rationale is that } \\
\text { this mixed methods review aims to } \\
\text { capture all studies designs that } \\
\text { report on risk factors and } \\
\text { characteristics from a range of } \\
\text { samples some of which may not } \\
\text { include studies with a comparator. }\end{array}$ & $\begin{array}{l}\text { Studies eligible for inclusion } \\
\text { whether or not they included a } \\
\text { comparator group. Rationale is } \\
\text { that this mixed methods review } \\
\text { aims to capture all studies designs } \\
\text { that report on risk factors and } \\
\text { characteristics from a range of } \\
\text { samples some of which may not } \\
\text { include studies with a comparator. }\end{array}$ \\
\hline Outcomes & $\begin{array}{l}\text { Stalking behaviour } \\
\text { Stalking recidivism/reoffending } \\
\text { Stalking behaviour measured on } \\
\text { self-report and/or official measures } \\
\text { Perpetrator and victim self-report } \\
\text { Paper must refer to a definition of } \\
\text { stalking. }\end{array}$ & $\begin{array}{l}\text { No evidence of stalking behaviour } \\
\text { Paper does not refer to definition } \\
\text { of stalking }\end{array}$ \\
\hline Study Design & $\begin{array}{l}\text { In line with the mixed methods } \\
\text { review, all study designs considered } \\
\text { to incorporate a wide range of study }\end{array}$ & $\begin{array}{l}\text { Reviews, policy documents, } \\
\text { commentaries, editorials, } \\
\text { discussion/opinion papers }\end{array}$ \\
\hline
\end{tabular}


designs, including quantitative, Data reported in a purely qualitative and mixed methods. descriptive manner without Note: Victim retrospective designs analysis

included if focus of study is on Studies which focus on victims' perceptions of perpetrator experiences or student samples characteristics exploration of stalking behaviour. The presence of a control group was *Note: Victim retrospective not stipulated. designs reporting solely on impact of stalking behaviour in victim will be excluded.

\section{Additional Written in English.} Written in other languages

Criteria $\quad$ Year of publication 1989-2018 Book chapters, editorials, literature reviews, narratives and opinion papers 
Table 2

Tabulation of Extracted Data: Summary of Study Characteristics

(Key: $\underline{\boldsymbol{D}}$ refers to studies retrieved through database search, and $\underline{\boldsymbol{H}}$ refers to studies retrieved through hand-searching)

\begin{tabular}{|c|c|c|c|c|c|c|c|}
\hline $\begin{array}{l}\text { Study } \\
\text { ID }\end{array}$ & $\begin{array}{c}\text { Title, } \\
\text { authors } \\
\text { and date }\end{array}$ & $\begin{array}{l}\text { Authors, } \\
\text { Date, } \\
\text { Country } \\
\text { of study }\end{array}$ & $\begin{array}{l}\text { Sample } \\
\text { and } \\
\text { setting }\end{array}$ & $\begin{array}{c}\text { Research } \\
\text { design and } \\
\text { data source }\end{array}$ & $\begin{array}{c}\text { Aim(s) and } \\
\text { focus of study }\end{array}$ & Results & $\begin{array}{c}\text { Quality assessment } \\
\text { score }\end{array}$ \\
\hline $\begin{array}{l}1 \\
\mathrm{D}\end{array}$ & $\begin{array}{l}\text { The } \\
\text { dangerous } \\
\text { nature of } \\
\text { intimate } \\
\text { relationshi } \\
\text { p stalking: } \\
\text { Threats, } \\
\text { violence } \\
\text { and } \\
\text { associated } \\
\text { risk } \\
\text { factors }\end{array}$ & $\begin{array}{l}\text { Palarea,et } \\
\text { al. (1999) } \\
\text { USA }\end{array}$ & $\begin{array}{l}\text { Forensic } \\
\text { setting } \\
\text { Offender } \\
\text { sample } \\
(n=223) \\
\\
\text { Police } \\
\text { data: } \\
\text { Compared } \\
223 \\
\text { intimates } \\
\text { and non- } \\
\text { intimate } \\
\text { stalking } \\
\text { cases } \\
\text { managed } \\
\text { by police } \\
\text { dept. }\end{array}$ & $\begin{array}{l}\text { Quantitative: } \\
\text { Observational } \\
\text { study } \\
\text { Data collection } \\
\text { method: } \\
\text { Revised Zona } \\
\text { profile - } \\
\text { Threat } \\
\text { Management } \\
\text { research } \\
\text { questionnaire } \\
\text { (Zona et al. } \\
\text { 1993) } \\
\text { Procedure: } \\
\text { Data taken } \\
\text { from pre- } \\
\text { existing police } \\
\text { database }\end{array}$ & $\begin{array}{l}\text { To investigate } \\
\text { the link } \\
\text { between the } \\
\text { presence of an } \\
\text { intimate } \\
\text { relationship } \\
\text { and dangerous- } \\
\text { ness level of } \\
\text { stalking } \\
\text { perpetration. }\end{array}$ & $\begin{array}{l}\text { Significant relationship } \\
\text { between perpetrators } \\
\text { intimate versus non- } \\
\text { intimate status and } \\
\text { violence committed } \\
\text { against persons and } \\
\text { property. The } \\
\text { relationship was } \\
\text { positively influenced by } \\
\text { level of proximity to the } \\
\text { victim and threats } \\
\text { towards property but } \\
\text { NOT influenced by } \\
\text { criminal, psychiatric, } \\
\text { IPV history. } \\
\text { Overall, intimate } \\
\text { partner stalkers used } \\
\text { more dangerous } \\
\text { stalking behaviours. }\end{array}$ & $\begin{array}{l}\text { Study quality score: } \\
70 \% \\
\text { Study quality category: } \\
\text { High }\end{array}$ \\
\hline
\end{tabular}




\begin{tabular}{|c|c|c|c|c|c|c|c|}
\hline & & & $\begin{array}{l}\text { Comparat } \\
\text { or group: } \\
\text { Intimate } \\
\text { relationshi } \\
\text { p cases } \\
(n=135) \\
\text { and non- } \\
\text { intimate } \\
\text { cases } \\
(n=88)\end{array}$ & $\begin{array}{l}\text { Form of } \\
\text { analysis: } \\
\text { multiple } \\
\text { regression }\end{array}$ & & & \\
\hline $\begin{array}{l}2 \\
\mathrm{D}\end{array}$ & $\begin{array}{l}\text { A pattern } \\
\text { of } \\
\text { violence: } \\
\text { Analyzing } \\
\text { the } \\
\text { relationshi } \\
\text { p between } \\
\text { intimate } \\
\text { partner } \\
\text { violence } \\
\text { and } \\
\text { stalking. }\end{array}$ & $\begin{array}{l}\text { Norris, } \\
\text { Huss, \& } \\
\text { Palarea } \\
\text { (2011) } \\
\text { Published, } \\
\text { USA }\end{array}$ & $\begin{array}{l}\begin{array}{l}\text { Offender } \\
\text { sample }\end{array} \\
\text { Forensic } \\
\text { setting } \\
(n=120) \\
\text { IPV } \\
\text { perpetrator } \\
\text { s self- } \\
\text { referred } \\
(28 \%) \text { or } \\
\text { court- } \\
\text { referred } \\
(62.6 \%) \\
\text { for IPV } \\
\text { treatment } \\
\text { Comparat } \\
\text { or group: } \\
\text { To }\end{array}$ & $\begin{array}{l}\text { Quantitative: } \\
\text { Observational } \\
\text { study } \\
\text { Data collection } \\
\text { method: } \\
\text { Interview \& } \\
\text { psychometrics } \\
\text { Measures: } \\
\text { Risk } \\
\text { Assessment } \\
\text { Inventory for } \\
\text { Stalking } \\
\text { (RAIS), } \\
\text { MCMI, Beck } \\
\text { Depression } \\
\text { Inventory, \& } \\
\text { multidimensio } \\
\text { nal Anger } \\
\text { Inventory }\end{array}$ & $\begin{array}{l}\text { Explored } \\
\text { levels of } \\
\text { severity } \\
\text { between } \\
\text { stalking- } \\
\text { related } \\
\text { behaviours and } \\
\text { IPV, and } \\
\text { differences } \\
\text { between IPV } \\
\text { perpetrators } \\
\text { who exhibited } \\
\text { stalking- } \\
\text { related } \\
\text { behaviours and } \\
\text { those who did } \\
\text { not. }\end{array}$ & $\begin{array}{l}\text { A significant } \\
\text { relationship between } \\
\text { stalking-related } \\
\text { behaviour and IPV was } \\
\text { found, with more severe } \\
\text { stalking related to } \\
\text { higher levels of IPV } \\
\text { and more extreme } \\
\text { psychopathology. } \\
\text { High psychological } \\
\text { abuse identified in } \\
\text { those who stalked, } \\
\text { suggesting } \\
\text { psychological } \\
\text { intimidation is } \\
\text { indicative of an IPV } \\
\text { perpetrator prone to } \\
\text { stalking against an } \\
\text { intimate partner. }\end{array}$ & $\begin{array}{l}\text { Study quality score: } \\
63 \% \\
\text { Study quality category: } \\
\text { Moderate }\end{array}$ \\
\hline
\end{tabular}




\begin{tabular}{|c|c|c|c|c|c|c|c|}
\hline & & & $\begin{array}{l}\text { examine } \\
\text { difference } \\
\text { s between } \\
\text { IPV who } \\
\text { engaged in } \\
\text { stalking- } \\
\text { related } \\
\text { behaviours } \\
\text { and } \\
\text { those who } \\
\text { do not. }\end{array}$ & $\begin{array}{l}\text { (self-report } \\
\text { measures) } \\
\text { Form of } \\
\text { analysis: Chi- } \\
\text { square, } \\
\text { ANOVas }\end{array}$ & & & \\
\hline & $\begin{array}{l}\text { An } \\
\text { empirical } \\
\text { analysis of } \\
\text { stalking as } \\
\text { a risk } \\
\text { factor in } \\
\text { domestic } \\
\text { violence }\end{array}$ & $\begin{array}{l}\text { Palarea } \\
(2005) \\
\text { USA, PhD } \\
\text { Thesis }\end{array}$ & $\begin{array}{l}\text { Offender } \\
\text { sample } \\
\text { Forensic } \\
\text { communit } \\
\text { y sample } \\
(\mathrm{n}=85) \\
\text { IPV } \\
\text { perpetrator } \\
\text { s (self- } \\
\text { referred or } \\
\text { court } \\
\text { ordered) to } \\
\text { a } \\
\text { communit } \\
\text { y IPV } \\
\text { treatment } \\
\text { program }\end{array}$ & $\begin{array}{l}\text { Quantitative: } \\
\text { Observational } \\
\text { study } \\
\text { Survey } \\
\text { Self-report } \\
\text { measures: Risk } \\
\text { Assessment } \\
\text { Inventory for } \\
\text { Stalking } \\
\text { (RAIS). } \\
\text { Conflict } \\
\text { Tactics Scale- } \\
\text { 2. } \\
\text { Form of } \\
\text { analysis: factor } \\
\text { analysis }\end{array}$ & $\begin{array}{l}\text { To assess for } \\
\text { stalking and } \\
\text { abuse within } \\
\text { participants } \\
\text { intimate } \\
\text { relationships. }\end{array}$ & $\begin{array}{l}\text { Motives for stalking } \\
\text { behaviours varied. } \\
\text { Findings indicated } \\
\text { rather than considering } \\
\text { stalking and IPV as } \\
\text { different constructs, } \\
\text { stalking behaviours } \\
\text { may be better } \\
\text { conceptualized as an } \\
\text { extension of the } \\
\text { physical and } \\
\text { psychological abuse } \\
\text { against the partner, with } \\
\text { more severe forms of } \\
\text { stalking being used by } \\
\text { more severe IPV } \\
\text { perpetrators. }\end{array}$ & $\begin{array}{l}\text { Study quality score: } \\
75 \% \\
\text { Study quality category: } \\
\text { High }\end{array}$ \\
\hline
\end{tabular}




\begin{tabular}{|c|c|c|c|c|c|c|c|}
\hline $\begin{array}{l}4 \\
\mathrm{H}\end{array}$ & $\begin{array}{l}\text { Re- } \\
\text { assessing } \\
\text { the link } \\
\text { between } \\
\text { stalking } \\
\text { and } \\
\text { intimate } \\
\text { partner } \\
\text { abuse }\end{array}$ & $\begin{array}{l}\text { McEwan } \\
\text { et al. } \\
\text { (2017) } \\
\text { Australia } \\
\text { published }\end{array}$ & $\begin{array}{l}\text { Offender } \\
\text { sample } \\
\text { Specialist } \\
\text { forensic/cl } \\
\text { inical } \\
\text { setting } \\
\text { (n=115) } \\
\text { Ex- } \\
\text { intimate } \\
\text { stalkers } \\
\text { who had } \\
\text { stalked } \\
118 \\
\text { separate } \\
\text { victims. } \\
\text { Recruited } \\
\text { from } \\
\text { specialist } \\
\text { forensic } \\
\text { clinic from } \\
\text { clients } \\
\text { referred } \\
\text { for } \\
\text { stalking } \\
\text { behaviour } \\
\text { to a } \\
\text { communit } \\
\text { y based }\end{array}$ & $\begin{array}{l}\text { Quantitative: } \\
\text { Observational } \\
\text { study } \\
\text { Data collection } \\
\text { method: } \\
\text { History of IPV } \\
\text { established } \\
\text { from self- } \\
\text { report and } \\
\text { police records } \\
\text { (Interview, } \\
\text { questionnaire, } \\
\text { existing case } \\
\text { file data). Data } \\
\text { from case } \\
\text { records/ } \\
\text { database taken } \\
\text { from } \\
\text { participants } \\
\text { and police. } \\
\text { Form of } \\
\text { analysis: } \\
\text { Univariate } \\
\text { analysis, } \\
\text { multivariate } \\
\text { modelling, } \\
\text { binary logistic } \\
\text { regression. }\end{array}$ & $\begin{array}{l}\text { To explore the } \\
\text { nature and link } \\
\text { between IPV } \\
\text { and stalking. } \\
\text { To identify } \\
\text { demographic, } \\
\text { clinical and } \\
\text { behavioural } \\
\text { variables that } \\
\text { differentiated } \\
\text { between ex- } \\
\text { intimate } \\
\text { stalkers who } \\
\text { had and had } \\
\text { not engaged in } \\
\text { prior IPA } \\
\text { against the } \\
\text { stalking } \\
\text { victim. }\end{array}$ & $\begin{array}{l}\text { Factors associated with } \\
\text { IPV during prior } \\
\text { relationship were: } \\
\text { Criminal history, prior } \\
\text { physical violence to } \\
\text { other victims, diagnosis } \\
\text { PD, sharing children - } \\
\text { significant association } \\
\text { IPV during prior } \\
\text { relationship. A history } \\
\text { of } \\
\text { violence toward others } \\
\text { and sharing children } \\
\text { with the victim } \\
\text { effectively } \\
\text { discriminated between } \\
\text { stalkers who did and } \\
\text { did not engage in prior } \\
\text { IPV. }\end{array}$ & $\begin{array}{l}\text { Study quality score: } \\
85 \% \\
\text { Study quality category: } \\
\text { High }\end{array}$ \\
\hline
\end{tabular}




\begin{tabular}{|c|c|c|c|c|c|c|c|}
\hline & & & $\begin{array}{l}\text { mental } \\
\text { health } \\
\text { service. }\end{array}$ & & & & \\
\hline $\begin{array}{l}5 \\
\mathrm{D}\end{array}$ & $\begin{array}{l}\text { Stalker } \\
\text { profiles } \\
\text { with and } \\
\text { without } \\
\text { protective } \\
\text { orders: } \\
\text { Reoffendi } \\
\text { ng or } \\
\text { criminal } \\
\text { justice } \\
\text { processing } \\
?\end{array}$ & $\begin{array}{l}\text { Logan et } \\
\text { al. (2002) } \\
\text { USA, } \\
\text { published }\end{array}$ & $\begin{array}{l}\text { Perpetrato } \\
\text { r sample } \\
\text { Forensic } \\
\text { setting } \\
(n=346) \\
\text { charged } \\
\text { with } \\
\text { stalking } \\
\text { crime. }\end{array}$ & $\begin{array}{l}\text { Quantitative: } \\
\text { Observational } \\
\text { study } \\
\text { Data collection } \\
\text { methods: } \\
\text { Existing } \\
\text { database. } \\
\text { Form of } \\
\text { analysis: Chi- } \\
\text { square }\end{array}$ & $\begin{array}{l}\text { To examine } \\
\text { characteristics } \\
\text { associated with } \\
\text { stalkers with } \\
\text { and without a } \\
\text { protective } \\
\text { order history. }\end{array}$ & $\begin{array}{l}\text { Two in three stalkers } \\
\text { had a protective order } \\
\text { either before or after } \\
\text { their stalking charge, } \\
\text { supporting an } \\
\text { association of stalking } \\
\text { with IPV. Stalkers with } \\
\text { a more extensive } \\
\text { history of protective } \\
\text { orders were also more } \\
\text { involved in the criminal } \\
\text { justice system. }\end{array}$ & $\begin{array}{l}\text { Study quality score: } \\
61 \% \\
\text { Study quality category: } \\
\text { Moderate }\end{array}$ \\
\hline $\begin{array}{l}6 \\
\mathrm{H}\end{array}$ & $\begin{array}{l}\text { The Abuse } \\
\text { of } \\
\text { Technolog } \\
\text { y } \\
\text { in } \\
\text { Domestic } \\
\text { Violence } \\
\text { and } \\
\text { Stalking }\end{array}$ & $\begin{array}{l}\text { Woodlock } \\
\text { (2017) } \\
\text { Australia, } \\
\text { published }\end{array}$ & $\begin{array}{l}\text { Victim } \\
\text { sample } \\
(n=46) \\
\text { Women } \\
\text { who had } \\
\text { experience } \\
\text { d IPS } \\
\text { Communit } \\
\text { y setting } \\
\text { Convenien } \\
\text { ce } \\
\text { sampling }\end{array}$ & $\begin{array}{l}\text { Qualitative } \\
\text { Observational } \\
\text { study (on-line } \\
\text { survey) } \\
\text { Two elements } \\
\text { Survey with } \\
\text { advocates and } \\
\text { victims. } \\
\text { Included in } \\
\text { review as } \\
\text { authors } \\
\text { separate out } \\
\text { findings }\end{array}$ & $\begin{array}{l}\text { Explores the } \\
\text { use of } \\
\text { technology to } \\
\text { facilitate } \\
\text { stalking and } \\
\text { other forms of } \\
\text { abuse. To } \\
\text { identify how } \\
\text { victims report } \\
\text { perpetrators } \\
\text { have used } \\
\text { technology to } \\
\text { stalk them. }\end{array}$ & $\begin{array}{l}\text { Technology used to } \\
\text { create a sense of } \\
\text { omnipresence, and to } \\
\text { isolate, punish, and } \\
\text { humiliate victims. } \\
\text { Perpetrators also } \\
\text { threatened to share } \\
\text { sexualized content } \\
\text { online. Findings } \\
\text { confirm that mobile } \\
\text { technologies are used } \\
\text { by perpetrators to stalk } \\
\text { and harass women. }\end{array}$ & $\begin{array}{l}\text { Study quality score: } \\
39 \% \\
\text { Study quality category: } \\
\text { Moderate }\end{array}$ \\
\hline
\end{tabular}




\begin{tabular}{|c|c|c|c|c|c|c|c|}
\hline \multirow[b]{2}{*}{$\begin{array}{l}7 \\
\mathrm{H}\end{array}$} & \multirow[b]{2}{*}{$\begin{array}{l}\text { Power and } \\
\text { control } \\
\text { dynamics } \\
\text { in pre- } \\
\text { stalking } \\
\text { and } \\
\text { stalking } \\
\text { situations }\end{array}$} & \multirow[b]{2}{*}{$\begin{array}{l}\text { Brewster } \\
(2003) \\
\text { USA, } \\
\text { published }\end{array}$} & \multirow[b]{2}{*}{$\begin{array}{l}\text { Victim } \\
\text { sample } \\
(n=187) \\
\text { victims } \\
\text { stalked by } \\
\text { former } \\
\text { partner } \\
\text { Communit } \\
\text { y setting } \\
\text { Convenien } \\
\text { ce sample }\end{array}$} & $\begin{array}{l}\text { Form of } \\
\text { analysis: } \\
\text { NVivo/themati } \\
\text { c analysis }\end{array}$ & \multirow[b]{2}{*}{$\begin{array}{l}\text { Examines the } \\
\text { role of power } \\
\text { and control in } \\
\text { stalking } \\
\text { situations and } \\
\text { in the prior } \\
\text { relationship } \\
\text { between } \\
\text { stalker and } \\
\text { victim. Reports } \\
\text { victims' } \\
\text { perceptions of } \\
\text { motivations. }\end{array}$} & \multirow[b]{2}{*}{$\begin{array}{l}\text { A greater number of } \\
\text { victims reported social } \\
\text { and physical control } \\
\text { than psychological, } \\
\text { financial, and sexual } \\
\text { control during the prior } \\
\text { relationship. } \\
\text { Psychological control } \\
\text { during stalking } \\
\text { campaign was reported } \\
\text { by nearly all victims. } \\
\text { Fewer than half of the } \\
\text { victims reported } \\
\text { physical assault during } \\
\text { the stalking, and just } \\
\text { over a quarter reported } \\
\text { financially controlling } \\
\text { behaviours. Authors } \\
\text { suggest that stalking is } \\
\text { extension of the abuse } \\
\text { of power and control } \\
\text { begins within the } \\
\text { relationship. }\end{array}$} & \multirow[b]{2}{*}{$\begin{array}{l}\text { Study quality score: } \\
61 \% \\
\text { Study quality category: } \\
\text { Moderate }\end{array}$} \\
\hline & & & & $\begin{array}{l}\text { Mixed } \\
\text { methods } \\
\text { Observational } \\
\text { study } \\
\text { Exploratory } \\
\text { study } \\
\text { Retrospective } \\
\text { Qualitative - } \\
\text { semi- } \\
\text { structured } \\
\text { interview to } \\
\text { explore } \\
\text { experiences of } \\
\text { victims } \\
\text { Forms of } \\
\text { analysis: } \\
\text { Content } \\
\text { analysis and } \\
\text { regression } \\
\text { models (two } \\
\text { linear and one } \\
\text { logistic) were } \\
\text { used to assess } \\
\text { the strength }\end{array}$ & & & \\
\hline
\end{tabular}


and statistical

significance of

the variables.

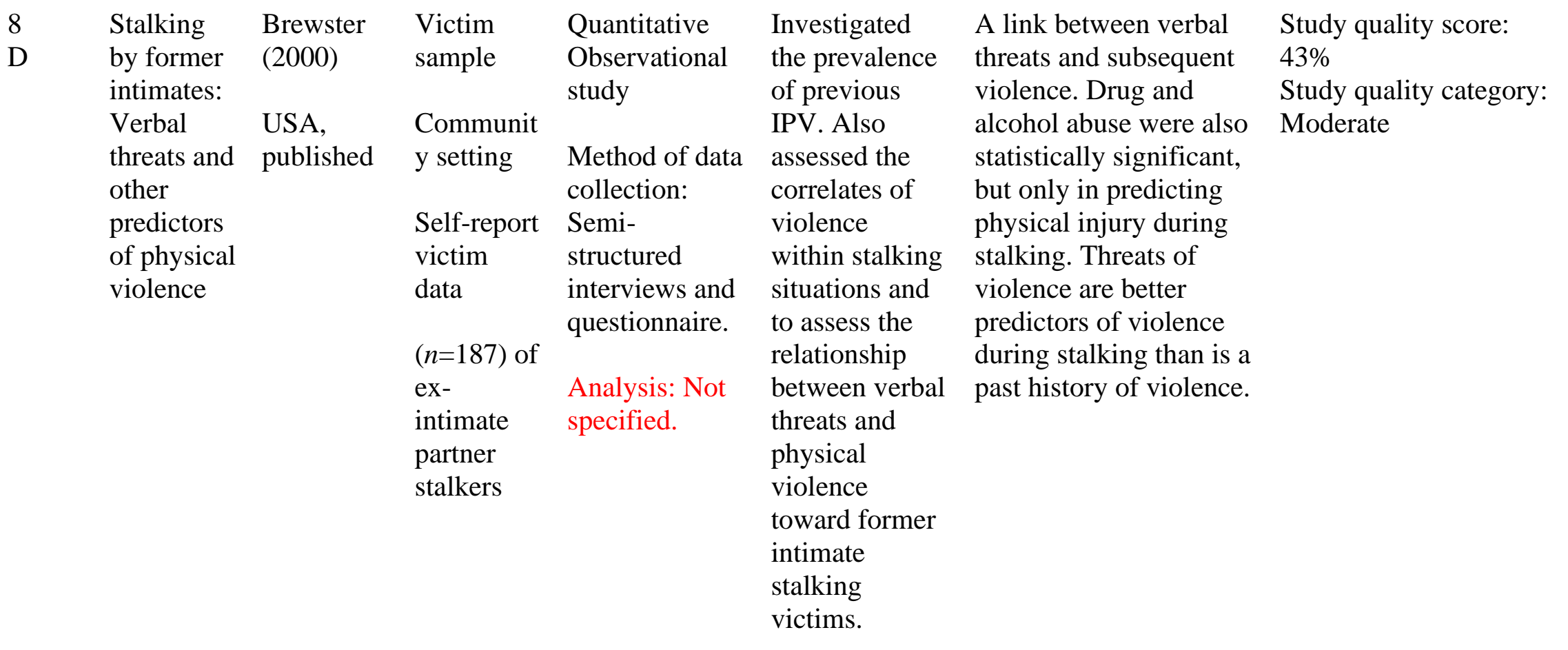




\begin{tabular}{|c|c|c|c|c|c|c|c|}
\hline D & $\begin{array}{l}\text { Predicting } \\
\text { the } \\
\text { occurrence } \\
\text { of stalking } \\
\text { in } \\
\text { relationshi } \\
\text { ps } \\
\text { characteris } \\
\text { ed by } \\
\text { domestic } \\
\text { violence }\end{array}$ & $\begin{array}{l}\text { Melton } \\
\text { (2007a) } \\
\text { USA, } \\
\text { Published }\end{array}$ & $\begin{array}{l}\begin{array}{l}\text { Victim } \\
\text { sample } \\
(n=178)\end{array} \\
\text { Communit } \\
\text { y setting } \\
\text { Victims } \\
\text { where } \\
\text { cases had } \\
\text { come into } \\
\text { contact } \\
\text { with } \\
\text { criminal } \\
\text { justice } \\
\text { system } \\
\text { Self- } \\
\text { selected } \\
\text { sample }\end{array}$ & $\begin{array}{l}\text { Quantitative } \\
\text { Observational } \\
\text { study } \\
\text { Data } \\
\text { collection: } \\
\text { Interviews, } \\
\text { survey \& case } \\
\text { file data. } \\
\text { Retrospective } \\
\text { design } \\
\text { Measures - } \\
\text { stalking } \\
\text { measures } \\
\text { collated using } \\
\text { stalking } \\
\text { behaviour } \\
\text { checklist } \\
\text { (Coleman, } \\
\text { 1997) } \\
\text { Form of } \\
\text { analysis: } \\
\text { Univariate } \\
\text { analysis } \\
\text { Bivariate } \\
\text { correlation } \\
\text { Cross } \\
\text { tabulations }\end{array}$ & $\begin{array}{l}\text { To investigate } \\
\text { what factors } \\
\text { predict } \\
\text { occurrence of } \\
\text { stalking in } \\
\text { relationships } \\
\text { with IPV } \\
\text { history. }\end{array}$ & $\begin{array}{l}\text { Factors which predicted } \\
\text { stalking were: victim } \\
\text { not in a relationship } \\
\text { with abuser, abuser had } \\
\text { alcohol or drug } \\
\text { problems, controlling } \\
\text { behaviour. }\end{array}$ & $\begin{array}{l}\text { Study quality score: } \\
75 \% \\
\text { Study quality category: } \\
\text { High }\end{array}$ \\
\hline
\end{tabular}




\begin{tabular}{|c|c|c|c|c|c|c|c|}
\hline 10 & $\begin{array}{l}\text { Risk } \\
\text { factors for } \\
\text { stalking } \\
\text { violence, } \\
\text { persistenc } \\
\text { e, and } \\
\text { recurrence }\end{array}$ & $\begin{array}{l}\text { McEwan } \\
\text { et al. } \\
\text { (2017) } \\
\text { Australia, } \\
\text { Published }\end{array}$ & $\begin{array}{l}\text { Perpetrato } \\
\text { r sample } \\
\text { Forensic } \\
\text { setting } \\
\text { ( } n=157 \\
\text { individual } \\
\text { s but } 143 \\
\text { male) } \\
\text { Ex- } \\
\text { intimate } \\
\text { sample } \\
(n=90)\end{array}$ & $\begin{array}{l}\text { Quantitative } \\
\text { study } \\
\text { Observational } \\
\text { study } \\
\text { Retrospective } \\
\text { design (both } \\
\text { outcomes of } \\
\text { stalking } \\
\text { violence, } \\
\text { persistence and } \\
\text { recurrence) } \\
\text { and predictors } \\
\text { had occurred at } \\
\text { time of data } \\
\text { collection) } \\
\text { Data collection } \\
\text { methods: } \\
\text { Interview, } \\
\text { psychometric } \\
\text { assessment, } \\
\text { and } \\
\text { supplementary } \\
\text { case file data. } \\
\text { Form of } \\
\text { analysis: } \\
\text { univariate } \\
\text { analyses. } \\
\text { Mann-Whitney } \\
\text { U tests used to }\end{array}$ & $\begin{array}{l}\text { Investigates } \\
\text { risk factors } \\
\text { associated with } \\
\text { stalking } \\
\text { violence, } \\
\text { persistence and } \\
\text { recurrence. }\end{array}$ & $\begin{array}{l}\text { Diverse risk factors } \\
\text { associated with } \\
\text { different stalking } \\
\text { outcomes. Violence } \\
\text { more likely to occur } \\
\text { with ex-intimate, } \\
\text { explicit threats or } \\
\text { property damage. } \\
\text { Strong relationship } \\
\text { between prior IPV } \\
\text { (physical) and stalking } \\
\text { violence. Results } \\
\text { confirm physical IPV } \\
\text { should be taken } \\
\text { seriously as unique risk } \\
\text { factor when managing } \\
\text { ex-intimate stalking } \\
\text { cases. }\end{array}$ & $\begin{array}{l}\text { Study quality score: } \\
80 \% \\
\text { Study quality category: } \\
\text { High }\end{array}$ \\
\hline
\end{tabular}




\begin{tabular}{|c|c|c|c|c|c|c|c|}
\hline \multirow[b]{2}{*}{$\begin{array}{l}11 \\
\mathrm{D}\end{array}$} & \multirow[b]{2}{*}{$\begin{array}{l}\text { The role } \\
\text { of stalking } \\
\text { in } \\
\text { domestic } \\
\text { violence } \\
\text { crime } \\
\text { reports } \\
\text { generated } \\
\text { by the } \\
\text { Colorado } \\
\text { Springs } \\
\text { police } \\
\text { departmen } \\
\text { t }\end{array}$} & \multirow[b]{2}{*}{$\begin{array}{l}\text { Tjaden \& } \\
\text { Thoennes } \\
(2000) . \\
\text { USA, } \\
\text { published }\end{array}$} & & $\begin{array}{l}\text { determine } \\
\text { relationships } \\
\text { with stalking } \\
\text { duration } \\
\text { Quantitative } \\
\text { Observational } \\
\text { study }\end{array}$ & & & \\
\hline & & & $\begin{array}{l}\text { Police } \\
\text { setting } \\
\text { Case file } \\
\text { review of } \\
\text { domestic } \\
\text { violence } \\
\text { crime } \\
\text { reports } \\
\text { from USA } \\
\text { Police } \\
\text { Departme } \\
\text { nt during a } \\
\text { nine- } \\
\text { month } \\
\text { period }\end{array}$ & $\begin{array}{l}\text { Forms of } \\
\text { analysis: } \\
\text { Series of } \\
\text { bivariate } \\
\text { analyses, } \\
\text { logistic } \\
\text { regression in } \\
\text { which several } \\
\text { independent } \\
\text { variables } \\
\text { representing } \\
\text { characteristics } \\
\text { of the victim } \\
\text { and suspect } \\
\text { were regressed } \\
\text { against the } \\
\text { dependent } \\
\text { variable. }\end{array}$ & $\begin{array}{l}\text { To investigate } \\
\text { the prevalence } \\
\text { of stalking in } \\
\text { domestic } \\
\text { violence } \\
\text { reports. To } \\
\text { explore the } \\
\text { risk factors } \\
\text { associated with } \\
\text { domestic } \\
\text { violence } \\
\text { stalking. To } \\
\text { elicit how } \\
\text { often intimate } \\
\text { partner stalkers } \\
\text { are charged } \\
\text { with stalking }\end{array}$ & $\begin{array}{l}\text { There is a link between } \\
\text { stalking and violence in } \\
\text { intimate relationships. } 1 \\
\text { in } 6(16.5 \%) \text { stalked } \\
\text { victim. Most } \\
\text { perpetrators were } \\
\text { former rather than } \\
\text { current intimates. } \\
\text { Reports of stalking } \\
\text { allegations were } \\
\text { significantly less likely } \\
\text { to mention physical } \\
\text { abuse or victim injury } \\
\text { in the presenting } \\
\text { condition to involve } \\
\text { households with } \\
\text { children, or to involve } \\
\text { victims and suspects } \\
\text { who were using alcohol } \\
\text { at the time of the report. } \\
\text { Police almost never } \\
\text { charged domestic } \\
\text { violence stalking } \\
\text { suspects with stalking, } \\
\text { instead charging them } \\
\text { with harassment or }\end{array}$ & $\begin{array}{l}\text { Study quality score: } \\
74 \% \\
\text { Study quality category: } \\
\text { High }\end{array}$ \\
\hline
\end{tabular}




\begin{tabular}{|c|c|c|c|c|c|c|c|}
\hline & & & & & & $\begin{array}{l}\text { violation of a } \\
\text { restraining order. }\end{array}$ & \\
\hline $\begin{array}{l}12 \\
D\end{array}$ & $\begin{array}{l}\text { Approach } \\
\text { and } \\
\text { escalation } \\
\text { in stalking }\end{array}$ & $\begin{array}{l}\text { McEwan } \\
\text { et al. } \\
\text { (2012) } \\
\text { Australia, } \\
\text { published }\end{array}$ & $\begin{array}{l}\text { Offender } \\
\text { sample } \\
\text { Communit } \\
\text { y/ } \\
\text { Forensic } \\
\text { sample } \\
\text { ( } n=211) \\
(n=71 \text { for } \\
\text { ex- } \\
\text { intimate } \\
\text { sample) } \\
\\
\text { Comparat } \\
\text { or group } \\
\text { used: } \\
\text { Former } \\
\text { sexual } \\
\text { intimates } \\
\text { and those } \\
\text { who were } \\
\text { not. }\end{array}$ & $\begin{array}{l}\text { Quantitative } \\
\text { Observational } \\
\text { study } \\
\text { Method of data } \\
\text { collection: } \\
\text { Interview, } \\
\text { collection of } \\
\text { demographic, } \\
\text { historical data } \\
\text { and } \\
\text { psychometric } \\
\text { instruments } \\
\text { Form of } \\
\text { analysis: Chi- } \\
\text { square analysis } \\
\text { and odds ratios } \\
\text { Effect side also } \\
\text { calculated }\end{array}$ & $\begin{array}{l}\text { To identify } \\
\text { variables } \\
\text { associated with } \\
\text { approach and } \\
\text { escalation } \\
\text { amongst ex- } \\
\text { intimates and } \\
\text { non-ex- } \\
\text { intimate } \\
\text { stalkers and to } \\
\text { compare the } \\
\text { latter with the } \\
\text { results of the } \\
\text { public figure } \\
\text { stalking. }\end{array}$ & $\begin{array}{l}\text { In non-ex-intimate } \\
\text { stalkers, approach was } \\
\text { associated with } \\
\text { psychosis and intimacy } \\
\text { motivation seeking. } \\
\text { The same applied to } \\
\text { escalation only more } \\
\text { strongly. No } \\
\text { associations with } \\
\text { approach or escalation } \\
\text { was found in ex- } \\
\text { intimate cases. }\end{array}$ & $\begin{array}{l}\text { Study quality score: } \\
78 \% \\
\text { Study quality category: } \\
\text { High }\end{array}$ \\
\hline $\begin{array}{l}13 \\
\mathrm{H}\end{array}$ & $\begin{array}{l}\text { The } \\
\text { intersectio } \\
\mathrm{n} \text { of } \\
\text { stalking } \\
\text { and the }\end{array}$ & $\begin{array}{l}\text { Brady \& } \\
\text { Hayes } \\
(2018)\end{array}$ & $\begin{array}{l}\text { Victim } \\
\text { sample } \\
\text { Communit } \\
\text { y setting }\end{array}$ & $\begin{array}{l}\text { Quantitative } \\
\text { Quasi- } \\
\text { experimental } \\
\text { design }\end{array}$ & $\begin{array}{l}\text { To examine } \\
\text { the link } \\
\text { between } \\
\text { stalking and } \\
\text { the severity of }\end{array}$ & $\begin{array}{l}\text { Victims of life } \\
\text { threatening abuse by an } \\
\text { intimate partner were } \\
\text { significantly more } \\
\text { likely to experience }\end{array}$ & $\begin{array}{l}\text { Study quality score: } \\
74 \% \\
\text { Study quality category: } \\
\text { High }\end{array}$ \\
\hline
\end{tabular}




\begin{tabular}{|c|c|c|c|c|c|}
\hline $\begin{array}{l}\text { severity of } \\
\text { intimate } \\
\text { partner } \\
\text { abuse }\end{array}$ & $\begin{array}{l}\text { USA, } \\
\text { Published }\end{array}$ & $\begin{array}{l}\text { ( } n=464) \\
\text { Data from } \\
\text { women's } \\
\text { health risk } \\
\text { study. } \\
\text { Sample of } \\
\text { abused } \\
\text { and non- } \\
\text { abused } \\
\text { women } \\
\text { from } \\
\text { hospitals } \\
\text { and clinics } \\
\text { and } \\
\text { intimate } \\
\text { partner } \\
\text { homicide } \\
\text { victims } \\
\text { from } \\
\text { proxy } \\
\text { interviews } \\
\text { and } \\
\text { official } \\
\text { records. }\end{array}$ & $\begin{array}{l}\text { Data collection } \\
\text { methods: face- } \\
\text { to-face } \\
\text { interviews and } \\
\text { questionnaire. } \\
\text { Measure/tool - } \\
\text { Harassment in } \\
\text { abusive } \\
\text { relationships: } \\
\text { (HARASS; } \\
\text { Sheridan, } \\
\text { 1992) } \\
\text { Form of } \\
\text { analysis } \\
\text { Univariate and } \\
\text { bivariate } \\
\text { analysis } \\
\text { conducted to } \\
\text { examine } \\
\text { associations } \\
\text { and } \\
\text { threatening } \\
\text { behaviour } \\
\text { across severity } \\
\text { of groups. Chi- } \\
\text { square \& } \\
\text { descriptive } \\
\text { statistics }\end{array}$ & $\begin{array}{l}\text { intimate } \\
\text { partner abuse } \\
\text { while } \\
\text { controlling for } \\
\text { previously } \\
\text { identified risk } \\
\text { factors of } \\
\text { intimate } \\
\text { partner } \\
\text { homicide. }\end{array}$ & $\begin{array}{l}\text { stalking than victims of } \\
\text { non-lethal abuse, (b) } \\
\text { after controlling for key } \\
\text { risk factors stalking } \\
\text { increased the risk of life } \\
\text { threatening abuse, (c) } \\
\text { threats to kill the victim } \\
\text { if she left was the only } \\
\text { significant stalking- } \\
\text { related behaviour that } \\
\text { increased the risk for } \\
\text { life threatening abuse, } \\
\text { (d) An offender's prior } \\
\text { record and a higher } \\
\text { number of previous } \\
\text { abusive incidents } \\
\text { increased the risk of } \\
\text { life-threatening abuse. }\end{array}$ \\
\hline
\end{tabular}




\begin{tabular}{|c|c|c|c|c|c|c|c|}
\hline $\begin{array}{l}14 \\
D\end{array}$ & $\begin{array}{l}\text { Intimate } \\
\text { partner } \\
\text { violence } \\
\text { and } \\
\text { stalking } \\
\text { behavior: } \\
\text { Exploratio } \\
n \text { of } \\
\text { patterns } \\
\text { and } \\
\text { correlates } \\
\text { in a } \\
\text { sample of } \\
\text { acutely } \\
\text { battered }\end{array}$ & $\begin{array}{l}\text { Mechanic, } \\
\text { et al. } \\
\text { (2000) } \\
\text { USA, } \\
\text { Published }\end{array}$ & $\begin{array}{l}\text { Victim } \\
\text { sample } \\
\text { Communit } \\
\text { y setting } \\
(n=114)\end{array}$ & $\begin{array}{l}\text { Quantitative: } \\
\text { Observational } \\
\text { study } \\
\text { (survey/intervi } \\
\text { ew) } \\
\text { Measures - } \\
\text { Stalking } \\
\text { Behaviour } \\
\text { Checklist } \\
\text { (SBC: } \\
\text { Coleman, } \\
\text { 1997). } \\
\text { The } \\
\text { Standardised } \\
\text { Battering } \\
\text { Interview \& } \\
\text { Psychological } \\
\text { Maltreatment } \\
\text { of Women } \\
\text { Inventory- } \\
\text { Abbreviated } \\
\text { Version } \\
\text { (PMWI) \& } \\
\text { Revised } \\
\text { Conflict } \\
\text { Tactics Scale-2 } \\
\text { (CTS-2). } \\
\text { Form of } \\
\text { analysis: } \\
\text { Regression } \\
\text { analyses }\end{array}$ & $\begin{array}{l}\text { To provide } \\
\text { descriptive } \\
\text { data on } \\
\text { stalking in a } \\
\text { sample of } \\
\text { acutely } \\
\text { battered } \\
\text { women and to } \\
\text { assess the } \\
\text { inter- } \\
\text { relationship } \\
\text { between } \\
\text { constructs of } \\
\text { emotional } \\
\text { abuse, physical } \\
\text { violence, and } \\
\text { stalking in } \\
\text { battered } \\
\text { women. }\end{array}$ & $\begin{array}{l}\text { Violent and harassing } \\
\text { stalking behaviours } \\
\text { occur with alarming } \\
\text { frequency among } \\
\text { physically battered } \\
\text { women, both while they } \\
\text { are in the relationship } \\
\text { and after they leave } \\
\text { their abusive partners. } \\
\text { Emotional and } \\
\text { psychological abuse } \\
\text { emerged as strong } \\
\text { predictors of within- } \\
\text { and post-relationship } \\
\text { stalking. }\end{array}$ & $\begin{array}{l}\text { Study quality score: } \\
61 \% \\
\text { Study quality category: } \\
\text { Moderate }\end{array}$ \\
\hline
\end{tabular}




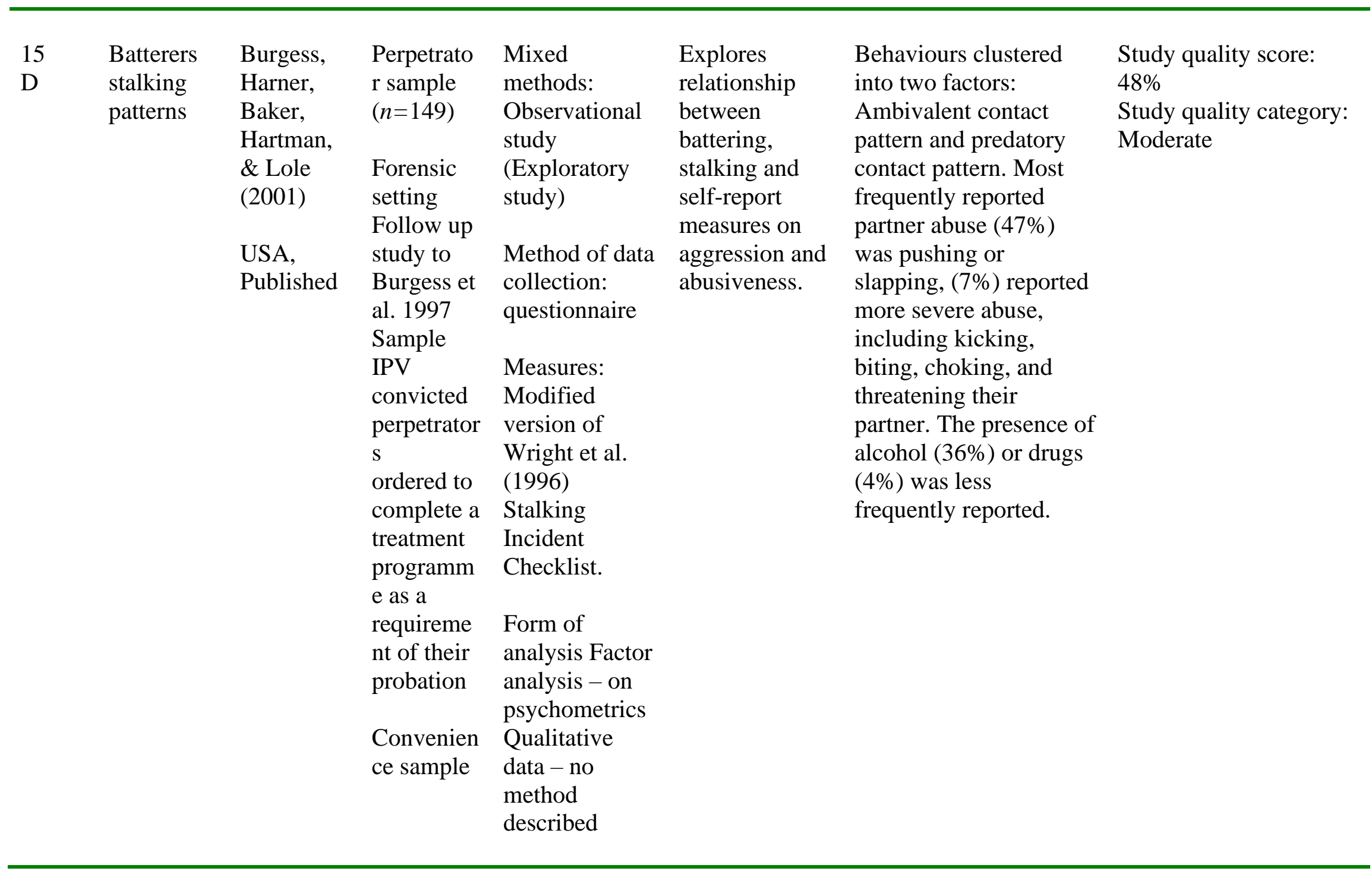




\begin{tabular}{|c|c|c|c|c|c|c|c|}
\hline $\begin{array}{l}16 \\
\mathrm{H}\end{array}$ & $\begin{array}{l}\text { Stalking } \\
\text { behaviors } \\
\text { within } \\
\text { domestic } \\
\text { violence. }\end{array}$ & $\begin{array}{l}\text { Burgess, } \\
\text { et al. } \\
\text { (1997) } \\
\text { USA, } \\
\text { Published }\end{array}$ & $\begin{array}{l}\text { Perpetrato } \\
\text { r sample } \\
(n=120) \\
\text { Separated } \\
\text { into } \\
\text { groups } \\
\text { based on } \\
\text { whether or } \\
\text { not } \\
\text { reported } \\
\text { stalking } \\
\text { Police/ } \\
\text { communit } \\
\text { y sample } \\
\text { Comparat } \\
\text { or group: } \\
\text { Compares } \\
\text { domestic } \\
\text { batters by } \\
\text { whether or } \\
\text { not they } \\
\text { admit to } \\
\text { stalking } \\
\text { Convenien } \\
\text { ce sample }\end{array}$ & $\begin{array}{l}\text { Quantitative } \\
\text { Observational } \\
\text { study } \\
\text { Exploratory } \\
\text { study } \\
\text { Data collection } \\
\text { method: } \\
\text { survey } \\
\text { Measures: } \\
\text { Stalking } \\
\text { checklist } \\
\text { developed and } \\
\text { published for } \\
\text { profiling } \\
\text { (Wright et al } \\
\text { 1996) for self- } \\
\text { report use with } \\
\text { domestic } \\
\text { violence } \\
\text { perpetrators } \\
\text { Form of } \\
\text { analysis: } \\
\text { Pearson } \\
\text { correlation }\end{array}$ & $\begin{array}{l}\text { To explore } \\
\text { differences, } \\
\text { between } \\
\text { domestic } \\
\text { violence cases } \\
\text { that have a } \\
\text { stalking } \\
\text { component and } \\
\text { those that do } \\
\text { not and to } \\
\text { explore if there } \\
\text { are patterns of } \\
\text { stalking } \\
\text { behaviours. }\end{array}$ & $\begin{array}{l}\text { ( } n=36) \text { reported } \\
\text { stalking, } 84,(70 \% \text { did } \\
\text { not). Variables } \\
\text { positively correlating } \\
\text { with a self-report of } \\
\text { stalking, including a } \\
\text { prior history of stalking } \\
\text { others, a history of } \\
\text { assault, alcohol abuse, } \\
\text { and living alone. } \\
\text { Identified several } \\
\text { variables that } \\
\text { differentiated stalking } \\
\text { from non-stalking } \\
\text { cases: prior surveillance } \\
\text { the incident occurring } \\
\text { in an open/public place, } \\
\text { less perception of } \\
\text { victim provocation, the } \\
\text { victim being strangled } \\
\text { or choked, and a prior } \\
\text { history of stalking. }\end{array}$ & $\begin{array}{l}\text { Study quality score: } \\
57 \% \\
\text { Study quality category: } \\
\text { Moderate }\end{array}$ \\
\hline $\begin{array}{l}17 \\
D\end{array}$ & $\begin{array}{l}\text { Stalking } \\
\text { and } \\
\text { Intimate }\end{array}$ & $\begin{array}{l}\text { McFarlane } \\
\text { et al. } \\
\text { (1999) }\end{array}$ & $\begin{array}{l}\text { Victim } \\
\text { sample } \\
(n=208)\end{array}$ & $\begin{array}{l}\text { Quantitative: } \\
\text { Observational } \\
\text { study }\end{array}$ & $\begin{array}{l}\text { Investigated } \\
\text { the incidence } \\
\text { of serious } \\
\text { violence to }\end{array}$ & $\begin{array}{l}\text { A statistically } \\
\text { significant association } \\
\text { existed between } \\
\text { intimate partner }\end{array}$ & $\begin{array}{l}\text { Study quality score: } \\
65 \% \\
\text { Study quality category: } \\
\text { Moderate }\end{array}$ \\
\hline
\end{tabular}




\begin{tabular}{|c|c|c|c|c|c|}
\hline $\begin{array}{l}\text { Partner } \\
\text { Femicide }\end{array}$ & $\begin{array}{l}\text { USA, } \\
\text { Published }\end{array}$ & $\begin{array}{l}\text { Forensic/c } \\
\text { linical } \\
\text { setting } \\
\text { Evaluation } \\
\text { of police } \\
\text { records. } \\
141 \\
\text { femicide } \\
\text { and } 65 \\
\text { attempted } \\
\text { femicide } \\
\text { incidents } \\
\text { Retrospect } \\
\text { ive sample }\end{array}$ & $\begin{array}{l}\text { Method of data } \\
\text { collection: } \\
\text { survey/intervie } \\
\text { w \& } \\
\text { psychometrics } \\
\text { Measures: } 18 \\
\text { item stalking } \\
\text { inventory and } \\
\text { personal } \\
\text { interviews } \\
\text { with proxy } \\
\text { informants and } \\
\text { victims. Used } \\
\text { the first } 6 \\
\text { items } \\
\text { developed by } \\
\text { Tjaden \& } \\
\text { Thoennes } \\
\text { (1998) } \\
\text { violence and } \\
\text { threats of } \\
\text { violence } \\
\text { against women } \\
\text { survey. } \\
\text { Twelve items } \\
\text { included from } \\
\text { Sheridan } \\
\text { (1998) } \\
\text { HARASS } \\
\text { instrument. }\end{array}$ & $\begin{array}{l}\text { determine risk } \\
\text { factors for } \\
\text { actual and } \\
\text { attempted } \\
\text { intimate } \\
\text { partner } \\
\text { femicide. To } \\
\text { determine } \\
\text { frequency and } \\
\text { type of } \\
\text { stalking that } \\
\text { preceded } \\
\text { attempted and } \\
\text { actual femicide }\end{array}$ & $\begin{array}{l}\text { physical assault and } \\
\text { stalking for femicide } \\
\text { victims as well as } \\
\text { attempted femicide } \\
\text { victims. Stalking is } \\
\text { revealed to be a } \\
\text { correlate of lethal and } \\
\text { near lethal violence } \\
\text { against women, coupled } \\
\text { with physical assault } \\
\text { and is significantly } \\
\text { associated with murder } \\
\text { and attempted murder. } \\
\text { Stalking should be } \\
\text { considered a risk factor } \\
\text { for femicide. }\end{array}$ \\
\hline
\end{tabular}




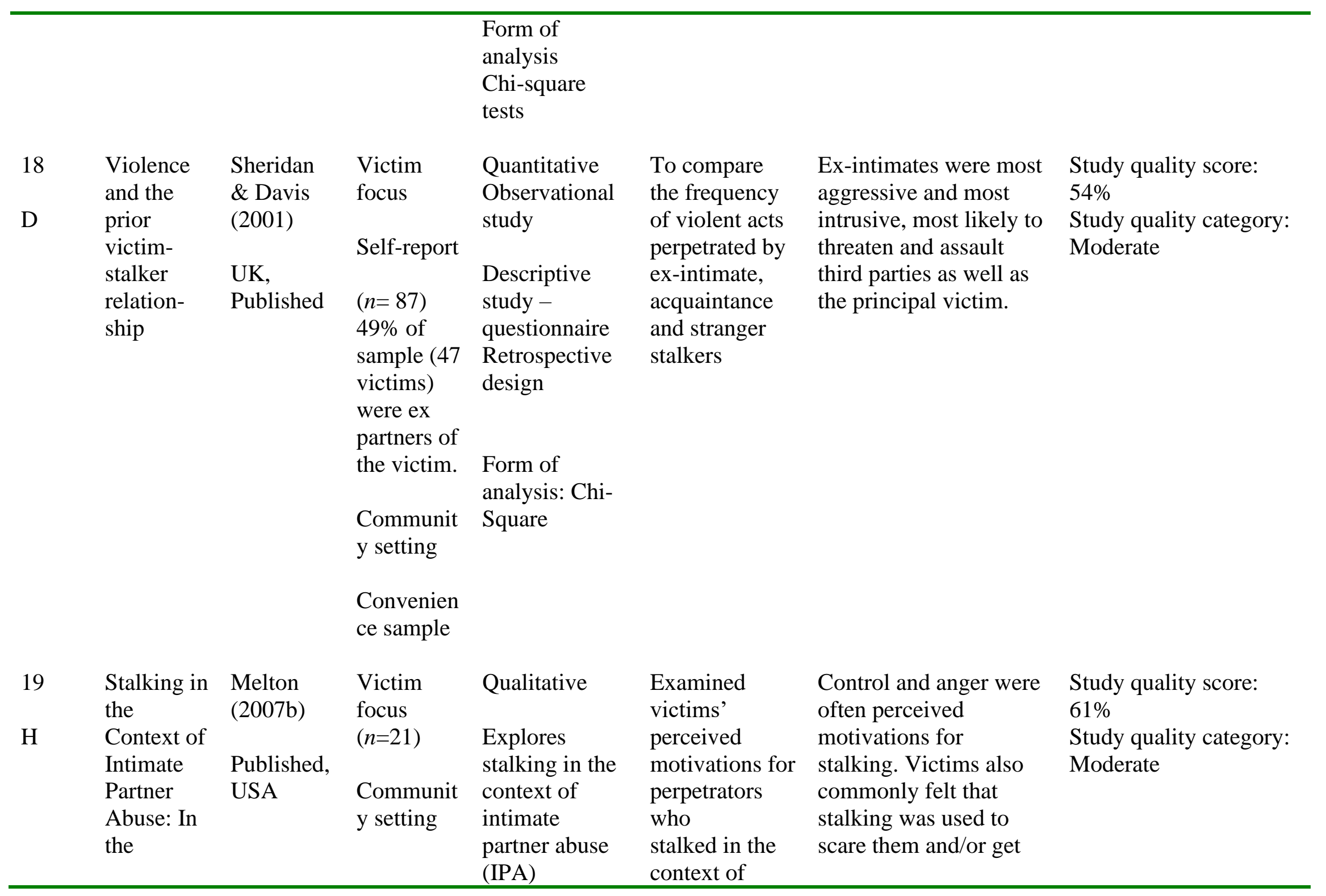




\begin{tabular}{|c|c|c|c|c|c|c|c|}
\hline & $\begin{array}{l}\text { victims' } \\
\text { words }\end{array}$ & & $\begin{array}{l}\text { Method of } \\
\text { data } \\
\text { collection: } \\
\text { Interviews } \\
\text { Convenien } \\
\text { ce } \\
\text { sampling }\end{array}$ & & $\begin{array}{l}\text { intimate } \\
\text { partner abuse. }\end{array}$ & $\begin{array}{l}\text { them to re-establish the } \\
\text { relationship. }\end{array}$ & \\
\hline 20 & $\begin{array}{l}\text { Post- } \\
\text { Relationsh } \\
\text { ip } \\
\text { Stalking: } \\
\text { The } \\
\text { Experienc } \\
\text { e of } \\
\text { Victims } \\
\text { With and } \\
\text { Without } \\
\text { History of } \\
\text { Partner } \\
\text { Abuse }\end{array}$ & $\begin{array}{l}\text { Ferreira \& } \\
\text { Matos } \\
\text { (2013) } \\
\text { Portugal, } \\
\text { Published }\end{array}$ & $\begin{array}{l}\text { Victim } \\
\text { sample } \\
\text { Communit } \\
\text { y setting } \\
\text { ( } n=107) \\
\text { Sample } \\
\text { women } \\
\text { stalked by } \\
\text { ex- } \\
\text { intimates } \\
\text { Comparat } \\
\text { or group } \\
\text { used: } \\
\text { Victims } \\
\text { with and } \\
\text { without a } \\
\text { prior } \\
\text { history of } \\
\text { IPV. }\end{array}$ & $\begin{array}{l}\text { Quantitative: } \\
\text { Observational } \\
\text { study } \\
\text { Retrospective } \\
\text { cohort design } \\
\text { Data collection } \\
\text { method: On- } \\
\text { line survey } \\
\text { Measures: } \\
\text { Partner } \\
\text { violence } \\
\text { inventory - } \\
\text { Part B Version } \\
\text { 3; Machado et } \\
\text { al 2006 \&The } \\
\text { Stalking } \\
\text { Behaviour } \\
\text { Inventory - } \\
\text { Version 2 } \\
\text { (SBI-2; }\end{array}$ & $\begin{array}{l}\text { To explore the } \\
\text { experience of } \\
\text { victims and } \\
\text { analyse the } \\
\text { differences } \\
\text { between post- } \\
\text { relationship } \\
\text { stalking } \\
\text { victims with } \\
\text { and without } \\
\text { history of } \\
\text { partner abuse. } \\
\text {. }\end{array}$ & $\begin{array}{l}\text { Victims who were } \\
\text { targets of past violence } \\
\text { suffered a more serious } \\
\text { post-relationship } \\
\text { stalking campaign. } \\
\text { Majority of participants } \\
\text { reported they had been } \\
\text { targets of violence } \\
\text { during the former } \\
\text { relationship with the } \\
\text { stalker. } 85 \% \text { reported } \\
\text { experiencing abuse } \\
\text { during the prior } \\
\text { relationship. }\end{array}$ & $\begin{array}{l}\text { Study quality score: } \\
70 \% \\
\text { Study quality category: } \\
\text { High }\end{array}$ \\
\hline
\end{tabular}




\begin{tabular}{|c|c|c|c|c|c|c|c|}
\hline \multirow[b]{3}{*}{$\begin{array}{l}21 \\
\mathrm{H}\end{array}$} & \multirow[b]{3}{*}{$\begin{array}{l}\text { Intimate } \\
\text { partner } \\
\text { stalking } \\
\text { and } \\
\text { femicide: } \\
\text { Urgent } \\
\text { implicatio } \\
\text { ns for } \\
\text { women's } \\
\text { safety }\end{array}$} & \multirow[b]{3}{*}{$\begin{array}{l}\text { McFarlane } \\
\text { et al. } \\
\text { (2002) } \\
\text { USA, } \\
\text { Published }\end{array}$} & \multirow{3}{*}{$\begin{array}{l}\text { Convenien } \\
\text { ce sample } \\
\\
\text { Victim } \\
\text { sample } \\
\text { (n=821) } \\
\text { Sample } \\
\text { victims of } \\
\text { attempted } \\
\text { or actual } \\
\text { femicide. } \\
263 \\
\text { femicides } \\
\text { and } 174 \\
\text { attempted } \\
\text { femicides. } \\
\\
\text { Data part } \\
\text { of a multi- } \\
\text { city study } \\
\text { to } \\
\text { determine } \\
\text { the risk } \\
\text { factors of } \\
\text { actual and } \\
\text { attempted } \\
\text { intimate }\end{array}$} & \multirow{2}{*}{$\begin{array}{l}\text { Grangeia et al } \\
\text { 2008) } \\
\text { Form of } \\
\text { analysis: } \\
\text { Parametric } \\
\text { tests }\end{array}$} & & & \\
\hline & & & & & & & \\
\hline & & & & $\begin{array}{l}\text { Data collection } \\
\text { methods: } \\
\text { Interviews and } \\
\text { Stalking and } \\
\text { Threatening } \\
\text { Behaviours } \\
\text { Inventory. } \\
\text { Form of } \\
\text { analysis: } \\
\text { Logistic } \\
\text { regressions }\end{array}$ & $\begin{array}{l}\text { Investigated } \\
\text { the incidence } \\
\text { of serious } \\
\text { violence in } \\
\text { retrospective } \\
\text { relationship. } \\
\text { Reports on the } \\
\text { associations } \\
\text { between IPS, } \\
\text { threatening } \\
\text { behaviors, and } \\
\text { femicide in } \\
\text { violent } \\
\text { intimate } \\
\text { relationships } \\
\text { compared with } \\
\text { an abused } \\
\text { cohort. Also } \\
\text { examine the } \\
\text { extent to which } \\
\text { specific } \\
\text { stalking and } \\
\text { threatening }\end{array}$ & $\begin{array}{l}\text { Victims who were } \\
\text { targets of past violence } \\
\text { suffered a more serious } \\
\text { post relationship } \\
\text { stalking campaign. } \\
\text { Women who reported } \\
\text { the perpetrator followed } \\
\text { or spied on them were } \\
\text { more than twice as } \\
\text { likely to become } \\
\text { attempted/actual } \\
\text { femicide victims. } \\
\text { Conclusions are that } \\
\text { certain stalking and } \\
\text { threatening behaviours } \\
\text { are strong risk factors } \\
\text { for lethality. }\end{array}$ & $\begin{array}{l}\text { Study quality score: } \\
61 \% \\
\text { Study quality category: } \\
\text { Moderate }\end{array}$ \\
\hline
\end{tabular}




\begin{tabular}{|c|c|c|c|c|c|c|c|}
\hline & & & $\begin{array}{l}\text { partner } \\
\text { femicide } \\
\text { Control } \\
\text { group }\end{array}$ & & $\begin{array}{l}\text { behaviors are a } \\
\text { potential risk } \\
\text { factor for } \\
\text { femicide. }\end{array}$ & & \\
\hline 22 & $\begin{array}{l}\text { The } \\
\text { tactical } \\
\text { face of } \\
\text { stalking }\end{array}$ & $\begin{array}{l}\text { Nicastro et } \\
\text { al. (2000) } \\
\text { USA, } \\
\text { Published }\end{array}$ & $\begin{array}{l}\text { Victim } \\
\text { sample } \\
(n=55) \\
\text { Retrospect } \\
\text { ive sample } \\
\text { of stalking } \\
\text { victims } \\
\text { case files } \\
\text { from } \\
\text { Domestic } \\
\text { Violence } \\
\text { Unit } \\
\text { Forensic } \\
\text { setting }\end{array}$ & $\begin{array}{l}\text { Quantitative } \\
\text { Observational } \\
\text { study } \\
\text { Data collection } \\
\text { methods: } \\
\text { Archive/case } \\
\text { file data } \\
\text { Form of } \\
\text { analysis: } \\
\text { Analyses of } \\
\text { variance and t- } \\
\text { tests }\end{array}$ & $\begin{array}{l}\text { To examine } \\
\text { the } \\
\text { demographic } \\
\text { and case } \\
\text { profile of } \\
\text { stalkers, to } \\
\text { explore the } \\
\text { relational } \\
\text { profile of } \\
\text { stalking cases. }\end{array}$ & $\begin{array}{l}\text { A history of violence } \\
\text { was reported in the } \\
\text { majority of case files } \\
\text { and the presence of } \\
\text { restraining order had a } \\
\text { strong correlation with } \\
\text { victimisation. } \\
76 \% \text { reported a history } \\
\text { of IPV. }\end{array}$ & $\begin{array}{l}\text { Study quality score: } \\
52 \% \\
\text { Study quality category: } \\
\text { Moderate }\end{array}$ \\
\hline
\end{tabular}




\section{Table 3}

Overarching themes and associated subthemes

\begin{tabular}{|c|c|c|}
\hline $\begin{array}{l}\text { Theme } \\
\text { Number }\end{array}$ & Overarching theme & Subtheme \\
\hline 1 & Perpetrator demographics & $\begin{array}{l}\text { 1a) Age } \\
\text { 1b) Educational attainment and employment } \\
\text { status } \\
\text { 1c) Race/ethnicity }\end{array}$ \\
\hline 2 & $\begin{array}{l}\text { Relationship history and } \\
\text { dynamics }\end{array}$ & $\begin{array}{l}\text { 2a) Victim-perpetrator relationship } \\
\text { 2b) Prior history of intimate partner violence }\end{array}$ \\
\hline 3 & $\begin{array}{l}\text { Perpetrator background } \\
\text { factors }\end{array}$ & $\begin{array}{l}\text { 3a) Psychological and clinical characteristics } \\
\text { 3b) History of substance misuse } \\
\text { 3c) Past criminal history }\end{array}$ \\
\hline 4 & Nature of stalking & $\begin{array}{l}\text { 4a) Onset of stalking: Motivation and triggers } \\
\text { 4b) Pursuit tactics } \\
\text { 4c) Threats and escalation }\end{array}$ \\
\hline
\end{tabular}


Figure 1: PRISMA 2009 Flow Diagram

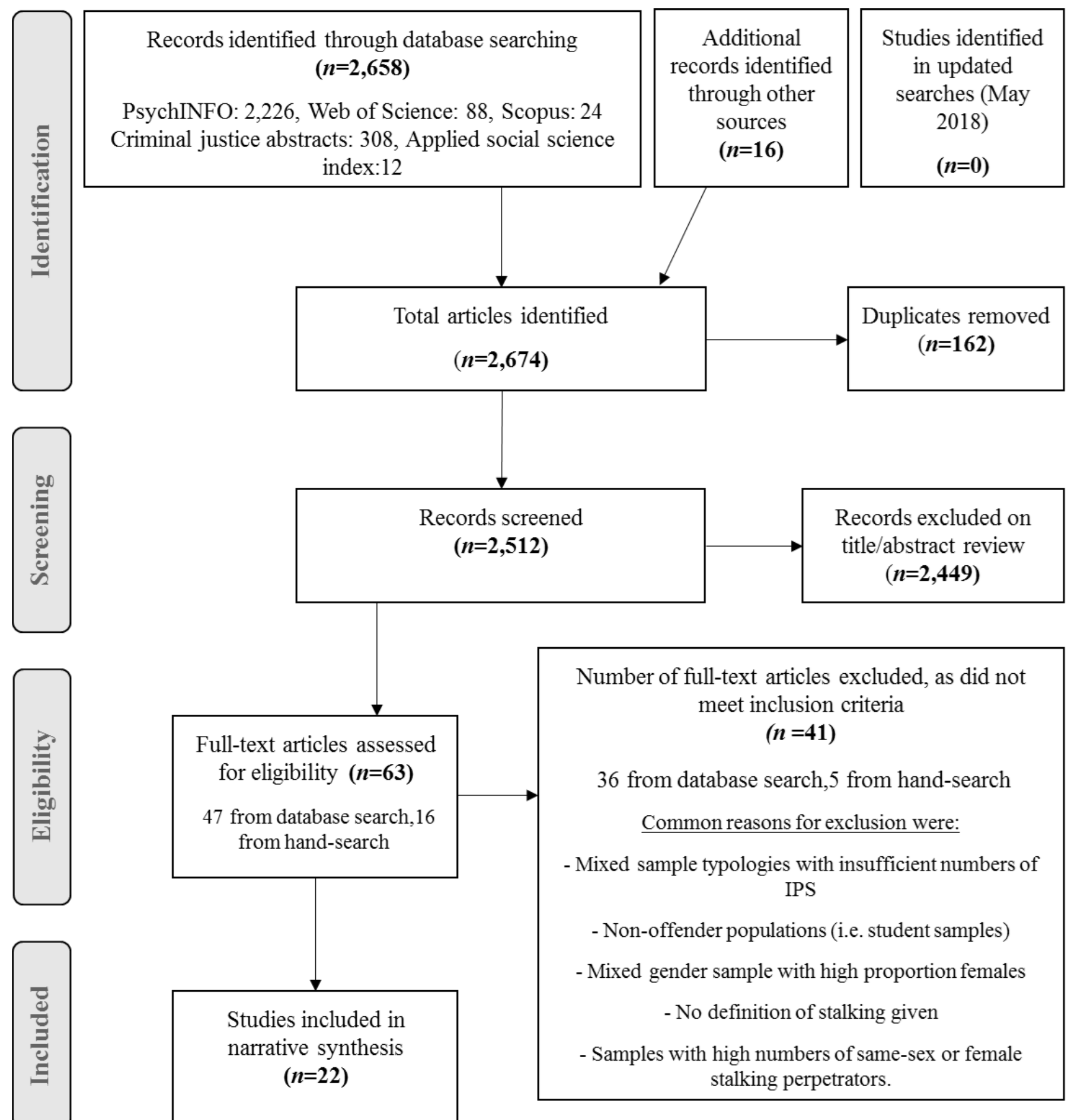

